\title{
Dinoflagellate cysts from the Oxfordian (Upper Jurassic) of Skye, Scotland and Southern Dorset, England.
}

\author{
R.P.W. STANCLIFFE \\ Department of Geological Sciences, University of Saskatchewan, Saskatoon, Saskatchewan, Canada.
}

\begin{abstract}
Ten sediment samples from Upper Oxfordian strata of Skye and six from the uppermost Lower Oxfordian of southern Dorset were processed for palynomorphs. Of the dinoflagellate cysts recognized, the genus Furzidinium and species F. sentum, Cleistosphaeridium sarmentum and Prolixosphaeridium floccum are described for the first time. The new combination Polygonium bavarica is proposed and Cleistosphaeridium ehrenbergi is retained.
\end{abstract}

\section{INTRODUCTION}

The modern era of Oxfordian dinoflagellate cyst research began in 1938 with the landmark paper by Deflandre on the microplankton of Villers-sur-Mer, northern France. Since then over sixty papers have been published (see Riley \& Sarjeant 1972, Courtinat 1989 for references) with descriptions of Oxfordian dinoflagellate cysts and their stratigraphic ranges. This database is such that the present paper need only describe new forms and comment on features which have not been reported previously. The other dinoflagellate cysts found in the study are listed in the distribution charts (Figs 11-12, Table 1) with selected examples being illustrated in Plates

For each of the species described the total body length, including the horn if present, but ignoring processes or any large ornament is given along with the breadth of the body. Cysts with an apical archeopyle have two length measurements: the specimens without an operculum (operc.) were measured separately from those with one. All size measurements are in micrometers $(\mu \mathrm{m})$ and, where possible, were rounded to the nearest integer. If more than 20 specimens of a species are recorded, the mean of the measurements is given in brackets between the range of values. This is only a guide and has no statistical significance due to the small sample size.

The rock samples used for this study are from Skye (Scotland) and southern Dorset (England). The section on Skye (Figs 1,2) was collected by the British Geological Survey and the ten samples (corresponding to slides GMUS E3107 to GMUSE3116 and specimen numbers MPK 9046 to MPK 9095) are from the Amoeboceras rosenkrantzi zone of Late Oxfordian age. Wright (1973, fig. 3) mapped the locality (NG 468-713) in his review of the Upper Oxfordian of Staffin, Isle of Skye. The six southern Dorset samples (corresponding to slides GMUS E2974 to GMUS E2979) were collected by Dr. J. K. Wright of the University of London from the Cardioceras cordatum zone, the upper ammonite zone of the Lower Oxfordian substage (Fig 3). A description of these sediments and a listing of the ammonites found at the locality (NG 700-818) was published by Wright (1986).

The sediment was processed at the University of Saskatchewan using

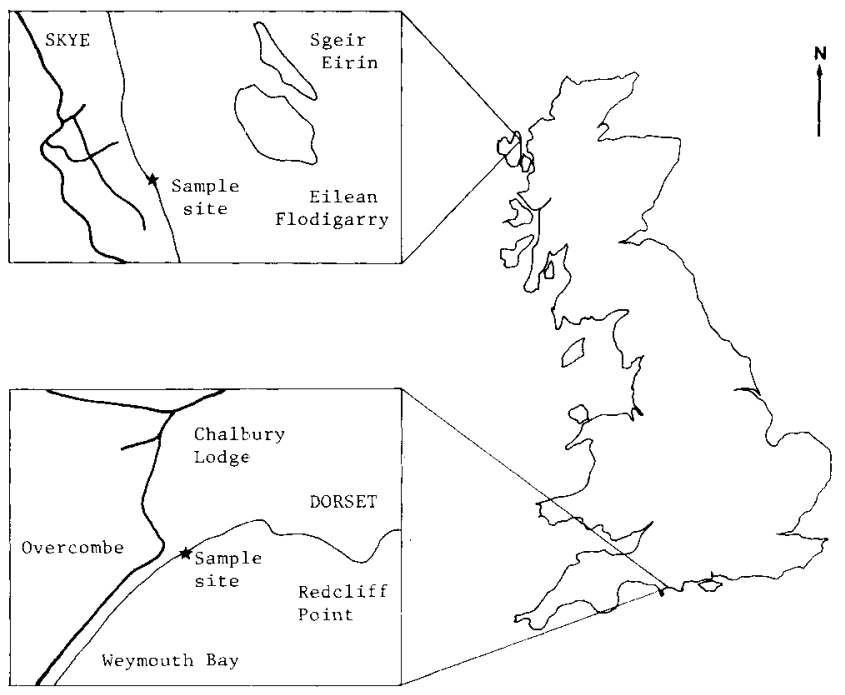

Fig. 1. Location map of the sample collection sites. For the two enlarged portions the scale is $7.8 \mathrm{~mm}$ to $\mathrm{lkm}$.

the standard fossil palynological preparation method. The organic residue was passed through $150 \mu \mathrm{m}$ and $12 \mu \mathrm{m}$ sieves with the 12 $150 \mu \mathrm{m}$ fraction mounted. The resulting slides from each sample are marked after the sample number (e.g., "GMUS E3100/1"). Three hundred marine palynomorphs were recorded from each sample (Figs 11-12). The slides made from Dorset sediment are stored in the collections of the palynology laboratory, Department of Geological Sciences, University of Saskatchewan, Saskatoon, Saskatchewan. Those from the Skye sediment are stored at the British Geological Survey, Keyworth, Nottinghamshire. 


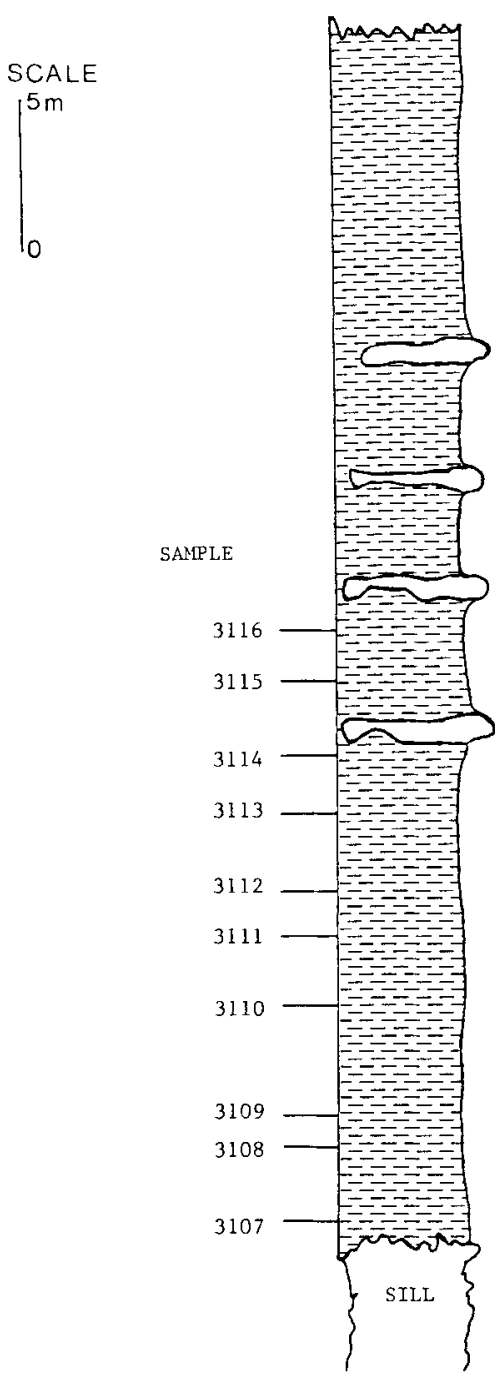

Fig. 2. Stratigraphic section sampled from near the Flodigarry Hotel, Skye, Scotland.

\section{SYSTEMATIC SECTION \\ Barbatacysta Courtinat 1989 \\ Barbatacysta cf. brevispinosa (Courtinat 1980) Courtinat 1989}

(Pl. 1, fig. 10; text-fig. 4)

Description. Subspherical proximate cyst with a granular autophragm. Approximately 200 processes, which are solid, short $(2-3 \mu \mathrm{m})$ and of variable width, are arranged over the body in an intratabular fashion. Processes may bifurcate along their length and distally may be acuminate, bifid, and rarely trifid. Cingulum distinctly laevorotatory, marked by two lines of processes with enlarged bases which occasionally are fused. A few isolated processes are developed within the cingulum. Sulcus located by a large sulcal notch and reduced process development. Apical archeopyle with zig-zag margin and short auxiliary sutures possibly surmounted with an attached operculum.

Dimensions. Skye: body length (no operc.) 28 (43) $64 \mu \mathrm{m}$, body breadth $23(45) 76 \mu \mathrm{m}$, process length 0.5 (1.5) $3 \mu \mathrm{m}$, number of processes 200-300+, number of specimens measured (recorded) 37 (52).

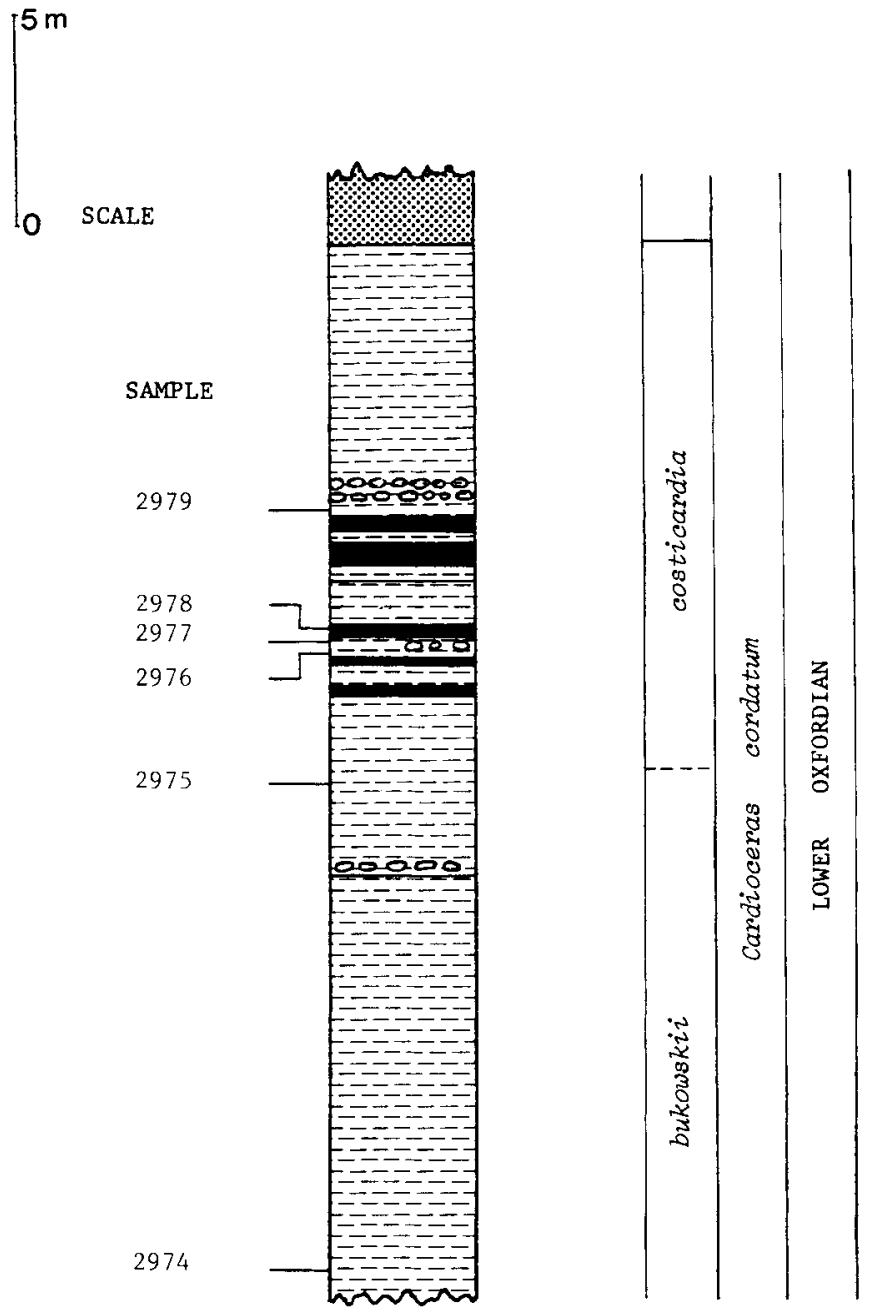

Fig. 3. Statigraphic section sampled from Furzy Cliff, South Dorset (after Wright, 1986).

Southern Dorset: body length (no operc.) $29-44 \mu \mathrm{m}$, body breadth $26-$ $33 \mu \mathrm{m}$, process length 1-3 $\mu \mathrm{m}$, number of processes $200-300+$, number of specimens measured (recorded) 13 (14).

Remarks. Differs from B. brevispinosa by having a more variable process morphology, well defined cingulum and a large sulcal notch.

\section{Barbatacysta creberbarbata (Erkmen and Sarjeant 1980) \\ Courtinat 1989}

(Pl. 1, fig. 11)

Dimensions. Skye: body length (no operc.) $27-49 \mu \mathrm{m}$, body breadth $26-34 \mu \mathrm{m}$, process length 2.5-5 $\mathrm{m}$, number of processes $200+$, number of specimens measured (recorded) 9 (13). Southern Dorset: body length (no operc.) $28-46 \mu \mathrm{m}$, body breadth $28-36 \mu \mathrm{m}$, process length 4-5 $\mu$ m number of processes $200-300+$, number of specimens measured (recorded) 4 (6).

Remarks. This species is very similar to Prolixosphaeridium capitatum (Cookson and Eisenack 1960) Singh 1971 and difficulty was encountered in their separation. The diagnosis of $P$. capitatum 


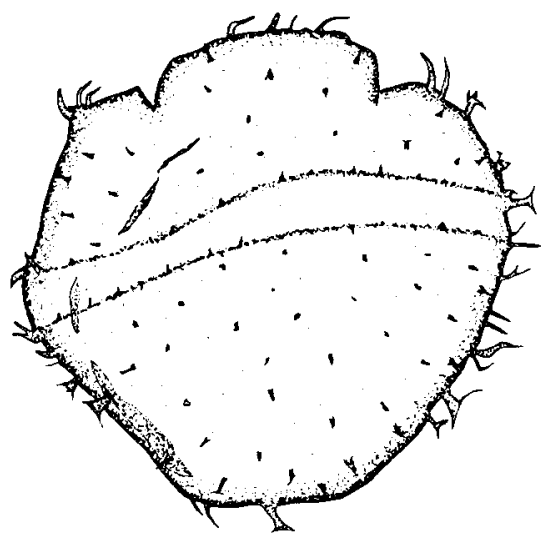

A

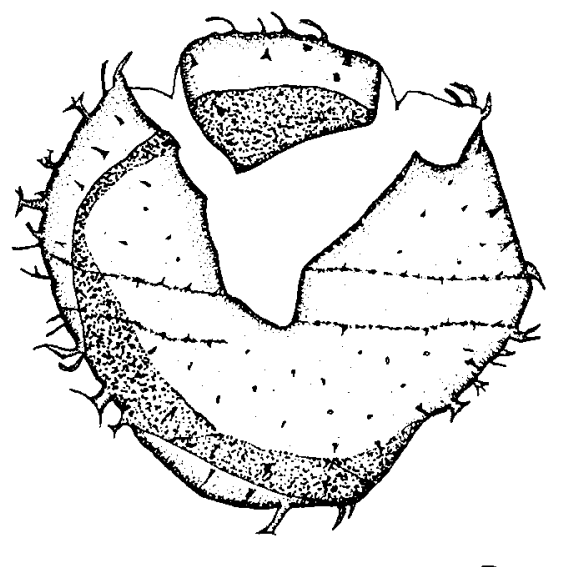

B
Fig. 4. Barbatacysta cf. brevispinosa (Courtinat 1980) Courtinat 1989. Slide GMUS E3111/2, England Finder coordinate F28/4, MPK 9046. A: dorsal (lower) surface. B: ventral (upper) surface. Magnification x 1050 does not include a reference to the possible alignment of the processes into rows. Singh (1971, p. 342-3) mentioned the lack of any process alignment on his specimen even though it is a prerequisite of the genus (Davey 1969, p. 160). The only recorded difference between $P$. capitatum and $B$. creberbarbata appears to be that the former is longer by $20 \mu \mathrm{m}$. The latter was first described by Erkmen and Sarjeant $(1980$, p. 52-4) and could be a junior synonym of $P$. capitatum. The two species are not synonymised, at the present time, as a restudy of the holotype of $P$. capitatum is required to determine if its morphology is consistent with the diagnosis of Barbatacysta.

Cleistosphaeridium Davey, Downie, Sarjeant \& Williams 1966 Cleistosphaeridium ehrenberqii (Deflandre 1947) Davey, Downie, Sarjeant and Williams 1969

(Pl. 1, fig. 7)

1989 Cleistosphaeridium deflandrei Courtinat: 166, pl. 12, fig. 5 ; pl. 13, fig. 12 .

Remarks. Courtinat (1989, p. 166) re-examined the plesiotype designated by Deflandre (1938) and gave a new diagnosis. He also decided to synonymise the species into a new species as he contended that the holotype was not designated, and a diagnosis was not given by Deflandre. While it is true that the name was published without strict adherence to the International Code of Botanic Nomenclature (I.C.B.N.) then in effect it is thought unnecessary to discard the name. Instead the diagnosis of C. ehrenbergii should be emended in the near future and a type specimen designated to conform with the I.C.B.N. presently in effect. The emended diagnosis of Courtinat (1989) is therefore rejected and the species Cleistosphaeridium deflandre $i$ is considered to be a junior synonym of $C$. ehrenbergii.

\section{Cleistosphaeridium sarmentum sp. nov.}

(Pl. 1, figs. 1-2; Pl. 2, fig. 6; text-fig. 5)

Derivation of name. Latin Sarmentum, twig or light branch, referring to the distal morphology of the processes.

Diagnosis. Skolochorate cyst with a sub spherical body; wall smooth to slightly granular. Processes isolated, non tabular, 28-40 in number, cover the body and are long (half to third of body width), hollow, generally straight, gently tapering distally and have slightly granular walls. Proximally the processes flare at the contact with the body but do not communicate with it. Distally the processes flare briefly at their tips, appear closed and have up to seven distal spines radiating from the process tip. Archeopyle apical with or without an attached opercuium.

Type material. Holotype; slide GMUS E3113/2, England Finder coordinate $\mathrm{H} 37 / 0$; Plate 1, Figures 1-2; Text-fig. 5.

Paratype; slide GMUS E3100/1, England Finder coordinate B37/4; Plate 2, Figure 6. Slides GMUS E3113/2 and GMUS E3100/1 are stored at the British Geological Survey, Keyworth, Nottinghamshire.

Dimensions $(\mu \mathrm{m})$.

$\begin{array}{llll} & \text { Skye } & \text { Holotype } & \text { Paratype } \\ \text { body length (no operc.) } & 26-37 & 26 & 27 \\ \text { body breadth } & 26-36 & 32 & 39 \\ \text { length of processes } & 10-19 & 10-13 & 13-19 \\ \text { number of processes } & 26-36 & 26 & 30 \\ \text { number measured } & 7(11) & & \\ \text { (recorded) } & & & \end{array}$
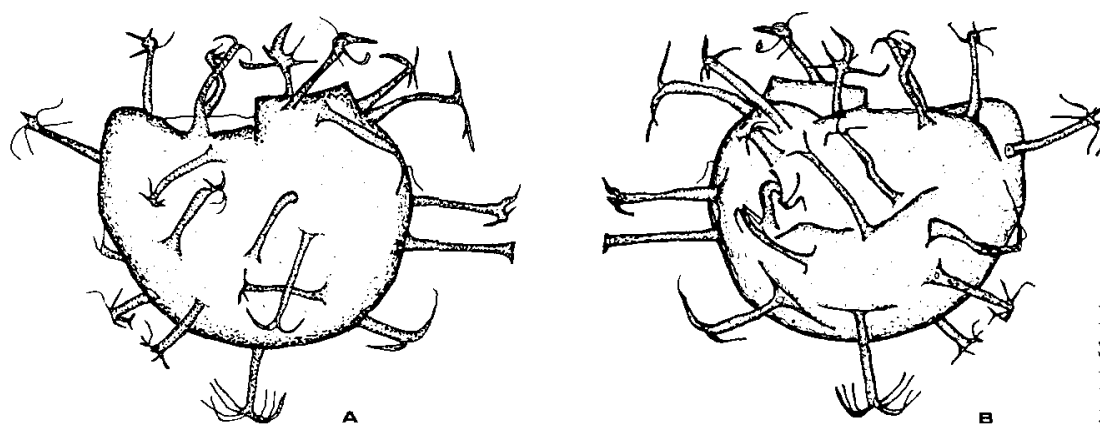

Fig. 5. Cleistosphaeridium sarmentum sp. nov. Holotype. Slide GMUS E3113/2, England Finder coordinate H37/0, MPK 9067. A: lower surface. B: upper surface. Magnification $\mathrm{x} 1050$. 
Occurrence. In the present study, the new species was only found in the Skye sequence which is of Late Oxfordian Age (Amoeboceras rosenkrantzi Zone). The range could extend into the Early Kimmeridgian (Pictonia bavlei Zone) if the specimens found by Gitmez (1970) are assigned to the species.

Remarks. These cysts have a morphology close to that of $C$.? tribuliferum (Sarjeant 1962) Davey, Downie, Sarjeant \& Williams 1966. Gitmez (1970, p. 288) included similar forms with a limited number of processes in the species but this is outside the range of the diagnosis as outlined by Sarjeant (1962, p. 487). A reexamination of these specimens would probably show that they can now be placed in $C$. sarmentum. No evidence of intergradation between these two species has been observed in the present study.

The species is differentiated from C.? tribuliferum by its smaller number of processes, more complex distal spine morphology and the relatively shorter process length as compared to the body width. No other species of Cleistosphaeridium has a similar combination of features. Hvstrichosphaeridium petilum Gitmez 1970 has fewer processes which are intra tabular.

\section{Furzidinium gen. nov.}

Derivation of name. Named after Furzy Cliff from which the type species was first reported.

Diagnosis. Sub spherical to sub polygonal proximochorate dinoflagellate cyst, phragma smooth to slightly granular. Epicyst is the same size to slightly smaller than the hypocyst. Ornament of thin, short to medium length, distally closed, probably solid processes mounted on very low sutural walls. The apex is marked by a small mamelon. Tabulation indistinct, formula probably 4', 6", ?6c, 6"', lp, $2 \mathrm{~s}, 1$ "'. Archeopyle epicystal.

Type species. Furzidinium sentum sp. nov.

Remarks. Other similar genera recorded from Upper Jurassic strata which have an epicystal archeopyle and ornament distributed over the cyst include Ctenidodinium Deflandre 1938 emend. Woollam 1983, Korystocysta Woollam 1983 and Dichadogonyaulax Sarjeant 1966. Furzidinium differs from Ctenidodinium by having an apical mamelon, and ornament of equal size on both sides of the cingulum. The genus differs from Dichadogonyaulax by its distribution of processes near the cingulum. The processes of Furzidinium are developed on the hypocystal side of the cingulum and not on the epicystal side. Korystocysta differs by having denticulate parasutural crests without processes and a different tabulation formula. All three forms have a distinctly laevorotatory cingulum which is not developed in Furzidinium.

Omatidium Courtinat 1980 emend. Courtinat 1989 has a precingular archeopyle as does Raphidodinium Deflandre 1936 and Hystrichodinium Deflandre 1935. Xiphophoridium Sarjeant 1966 has an apical archeopyle and longer processes. Luehndea Morgenroth 1970 has 3 intercalary plates, longer more lanceolate processes and does not have a-mamelon. Cauca Davey \& Verdier 1974 always has longer more robust processes and never shows the development of apical structures.

Furzidinium sentum sp. nov.

(Pl. 1, fig. 4; Pl. 3, figs. 4, 5, 9; Pl. 4, fig. 5; text-figs. 6-7)

Derivation of name. Latin, Sentis, thorn, referring to the shape of the processes.

Diagnosis. Spherical to sub polygonal proximochorate dinoflagellate cyst, phragma smooth to granular. Epicyst is equal to or slightly smaller than the hypocyst and the ornament size is similar on both halves of the cyst. Ornament composed of thin, fragile, short to medium length, distally closed, probably solid processes. The apex is marked by a small mamelon. Tabulation generally poorly developed, formula probably 4', 6", ?6c, 6"', lp, 2s, 1"': the cingulum is well defined by low parallel walls. Archeopyle epicystal with the operculum occasionally retained.

\section{Type material.}

Holotype; slide GMUS E2975/2, England Finder coordinate C33/1: Plate 4, Figure 5i Text-figure 6.

Paratype; 1. Slide GMUS E2976/3, England Finder coordinate C32/ 0 ; Plate 1, Figure 4i Text-figure 7a.

Paratypei 2. Slide GMUS F2978/2, England Finder coordinate F43/ 2; Plate 3, Figure 9; Text-figure $7 \mathrm{~b}$.

Paratype; 3. Slide GMUS E2975/3, England Finder coordinate B43/ 1; Plate 3, Figure 5; Text-figure 7c. Slides GMUS E2975/2, GMUS E2978/2, GMUS E2976/3, GMUS E2975/3, are stored in the Department of Geological Sciences, University of Saskatchewan, Saskatoon, Canada.

\section{Explanation of Plate 1}

Figs. 1-2. Cleistosphaeridium sarmentum sp. nov. Holotype. Slide GMUS E3113/2, England Finder coordinate H37/0, MPK 9047. Lateral view, phase contrast, magnification circa $\times 1150$.

Fig. 3; Pilosidinium echinatum (Gitmez and Sarjeant 1972) Courtinat 1989. GMUS E2974/1, England Finder coordinate C35/0. Dorso-ventral view, phase contrast, magnification circa $x 650$.

Fig. 4. Furzidinium sentum sp. nov. Paratype 1. Slide GMUS E2976/3, England Finder coordinate C32/0. Lateral view, phase contrast, the epicyst with a well developed mamelon has slightly rotated into the hypocyst. Magnification circa x1200.

Fig. 5. Ctenidodinium tenellum Deflandre 1938. Slide GMUS E2977/2, England Finder coordinate C32/2. Lateral view, phase contrast, magnification circa x650. Fig. 6. Chytroeisphaeridia chytroeides (Sarjeant 1962); emend. Davey 1979. Slide GMUS E3108/2, England Finder coordinate H38/4, MPK 9063. Dorso-ventral view, phase contrast, magnification circa x650.

Fig. 7. Cleistosphaeridium ehrenbergii (Deflandre 1947) Davey, Downie, Sarjeant and Williams 1969. Slide GMUS E2977/1, England Finder coordinate B46/ 3. Lateral view, phase contrast, magnification circa $\times 650$.

Fig. 8. Cleistosphaeridium? tribuliferum (Sarjeant 1962) Davey, Downie, Sarjeant and Williams 1969. Slide GMUS E2976/1, England Finder coordinate E31/ 1. Lateral view, phase contrast, magnification circa x650.

Fig. 9. Systematophora valensii (Sarjeant 1960) Downie and Sarjeant 1964. Slide GMUS E3109/1, England Finder coordinate R38/4, MPK 9066. Lateral view, phase contrast, magnification circa $\mathbf{6 5 0 .}$.

Fig. 10. Barbatacysta cf. brevispinosa (Courtinat 1980) Courtinat 1989. Slide GMUS E3111/2, England Finder coordinate F28/4, MPK 9046. Dorso-ventral view, phase contrast, magnification circa 6650 .

Fig. 11. Barbatacysta creberbarbata (Erkmen and Sarjeant 1980) Courtinat 1989. Slide GMUS E3111/4, England Finder coordinate H43/0, MPK 9067. Dorsoventral view, phase contrast, magnification circa $\times 1000$. 

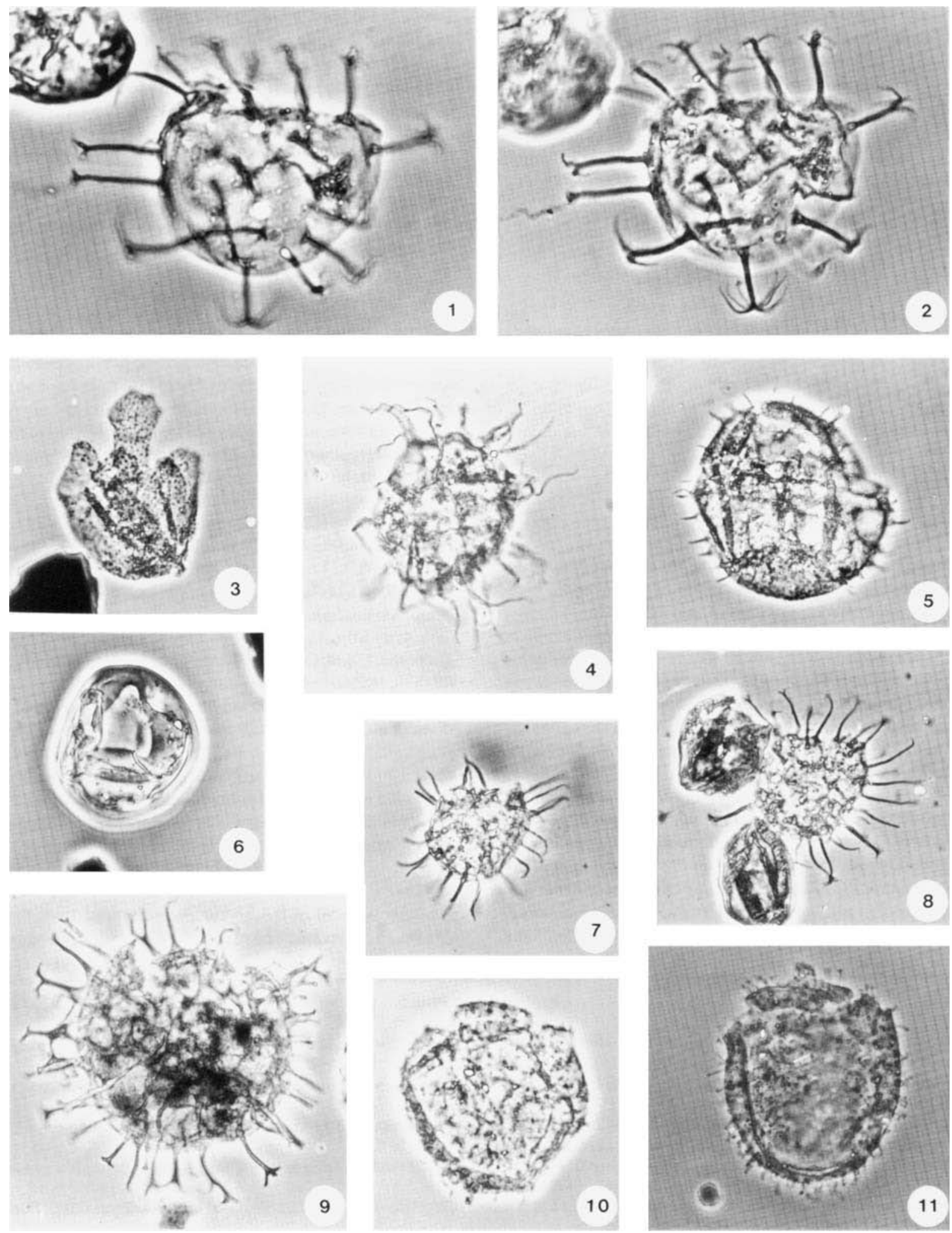
Occurrence. Holotype specimen from sample 2975, Furzy Cliff, southern Dorset, Lower Oxfordian, Jurassic. Reported occurrences from the Cardioceras cordatum and Amoeboceras rosenkrantzi zones of the Oxfordian, Jurassic of Britain.

Dimensions. $(\mu \mathrm{m})$.

\begin{tabular}{ll} 
& Holotype \\
$\begin{array}{ll}\text { body length } \\
\text { hypocyst length }\end{array}$ & 26 \\
$\begin{array}{l}\text { body breadth } \\
\text { mamelon length }\end{array}$ & 26 \\
$\begin{array}{l}\text { length of } \\
\text { processes } \\
\text { number of } \\
\text { processes }\end{array}$ & 9 \\
\hline
\end{tabular}

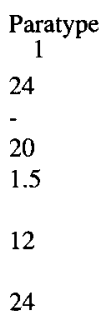

$\underset{2}{\text { Paratype }}$
24
-
22
1.5
3
32

Overall dimensions. $(\mu \mathrm{m})$.

$\begin{array}{lll}\text { body length } & \text { Skye } & \text { Southern Dorset } \\ \text { hypocyst length } & 21-39 & 24-30 \\ \text { body breadth } & 19-21 & 16-24 \\ \text { mamelon length } & 17-36 & 21-29 \\ \text { length of processes } & 1-2 & 1-2 \\ \text { number of processes } & 3-12 & 6-15 \\ \text { number measured (recorded) } & 10-19+ & 15-37 \\ & 14(14) & 17(17)\end{array}$

Remarks. In the assemblages studied, the species was found both with and without the epicyst though the former state is much more common. The larger processes are gonal, and there is occasionally a bifurcation at their base into two long processes. Intergonal processes are best, though not exclusively, developed at the contact of the apical and precingular plates on the epicyst and at the contact of the postcingular and antapical plate. Processes are developed on the hypocystal side of the cingulum but were not observed on the epicystal side. The wide cingulum is marked by low walls of equal height which are larger than those marking the sutures. The operculum is probably adherent in nature. Where the operculum is not retained, the edge of the archeopyle is smooth around the cyst without the development of a sulcal tab projecting from the edge of the opening (see PI. 3, Figs 4, 9). This feature makes the interpretation of the sulcal area unique but the lack of a sulcal tab combined with the well developed cingulum precludes other more classical interpretations. The apical mamelon is always present; its tip does not accept stain and under phase illumination appears darker than the rest of the apex. The species is superficially similar to Cauca parva (Alberti 1961) Davey \& Verdier 1971 from the Albian of the Paris Basin. In their diagnosis of the genus, Davey \& Verdier specifically state that Cauca has no polar structures and the sutural processes are always long: morphologies not shown by Furzidinium sentum. A comparison with Hystrichodinium pulchrum Deflandre 1935 shows that $F$. sentum has no pores on the phragma, always a very poorly laevorotatory cingulum marked by distinct walls and only an epicystal archeopyle. Furthermore, $F$. sentum has processes only developed on the hypocystal side of the cingulum, and the largest processes are gonal and occasionally bifid. These features have not been reported as developed by either of the other two species.

\section{Netrelytron Sarjeant 1961a \\ Netrelytron stegastum Sarjeant 1961 a}

(Pl. 2, fig. 4)

Remarks. The illustrated specimen from the southern Dorset sequence does not have a well developed archeopyle but does have an extended apical structure. This is 'rod like' and similar to those developed by Pareodinia ceratophora Deflandre 1947. A second specimen was found in the southern Dorset sequence which is compressed vertically though a similar apical horn extension is preserved.

\section{Polygonifera Habib 1972; emend. Mehrotra \& Sarjeant 1984} Polygonifera bavarica (Lund \& Ecke 1988) comb. nov.

$$
\text { (Pl. 4, fig. 2) }
$$

1972 Evittia waltonii Pocock: pl. 22, fig. 14

1988 Ambonosphaera bavarica Lund \& Ecke: 348-351, pl. 1, figs. 2a-b, 4, text-fig. 3a-b.

Holotype. 256.Im Ortenburg 1 well, East Bavaria(TK 7445 Ortenburg R91880, H82484). Middle Oxfordian (Jurassic). Possibly stored at Bayerisches Geologisches Landesamt, Munich, Germany.

Remarks. The species was placed in Ambonosphaera by Lund \& Ecke $(1988$, p. $348-351)$ but the generic diagnosis outlined by Fensome (1979. p. 50-51) requires constituent species to be cavate and have a well developed paratabulation. P. bavarica does not have a resolvable paratabulation and is therefore transferred to $P$ olygonifera. The inclusion of Pocock's (1972) record in the synonymy listing is based on his photograph. Jansonius (1986, p. 202) reported that the specimen is now lost.

The type material of this species was recorded from the Middle Oxfordian of Bavaria. The range of the species is now increased to

Explanation of Plate 2

Fig. 1. Leptodinium freakei (Sarjeant 1963) Sarjeant 1969. Slide GMUS E3112/2, England Finder coordinate J37/0, MPK 9068. Lateral view, phase contrast, magnification circa $\times 550$.

Figs. 2-3. Prolixosphaeridium floccum sp. nov. Holotype. Slide GMUS E31 15/2, England Finder coordinate N43/1, MPK 9052. 2: dorsal view, 3: ventral view, normal illumination, magnification circa $\times 1050$.

Fig. 4. Netrelytron stegastum Sarjeant 1961a. Slide GMUS E2979/2, England Finder coordinate H40/1. ?Lateral view, phase contrast. Note the 'rod like' apical structure. Magnification circa x550.

Fig. 5. Cleistosphaeridium sarmentum sp. nov. Paratype. Slide GMUS E3100/1, England Finder coordinate B37/4, MPK 9070. ?Lateral view, phase contrast, magnification circa $\times 750$.

Fig. 6. Senoniasphaera jurassica (Gitmez and Sarjeant 1972) Lentin and Williams 1976. Slide GMUS E2971/1, England Finder coordinate G31/2. Dorso-ventral view, phase contrast, magnification circa $x 750$.

Fig. 7. Scriniodinium crystallinum (Deflandre 1938) Klement 1960. Slide GMUS E3112/1, England Finder coordinate G30/0, MPK 9053. Dorso-ventral view, normal illumination, magnification circa $\times 450$.

Figs. 8-9. Prolixosphaeridium floccum sp. nov. Paratype 1. Slide GMUS E31 15/2, England Finder coordinate U46/1, MPK 9072. 8: dorsal view, 9: ventral vi.ew, phase contrast, magnification circa $\times 1050$. 

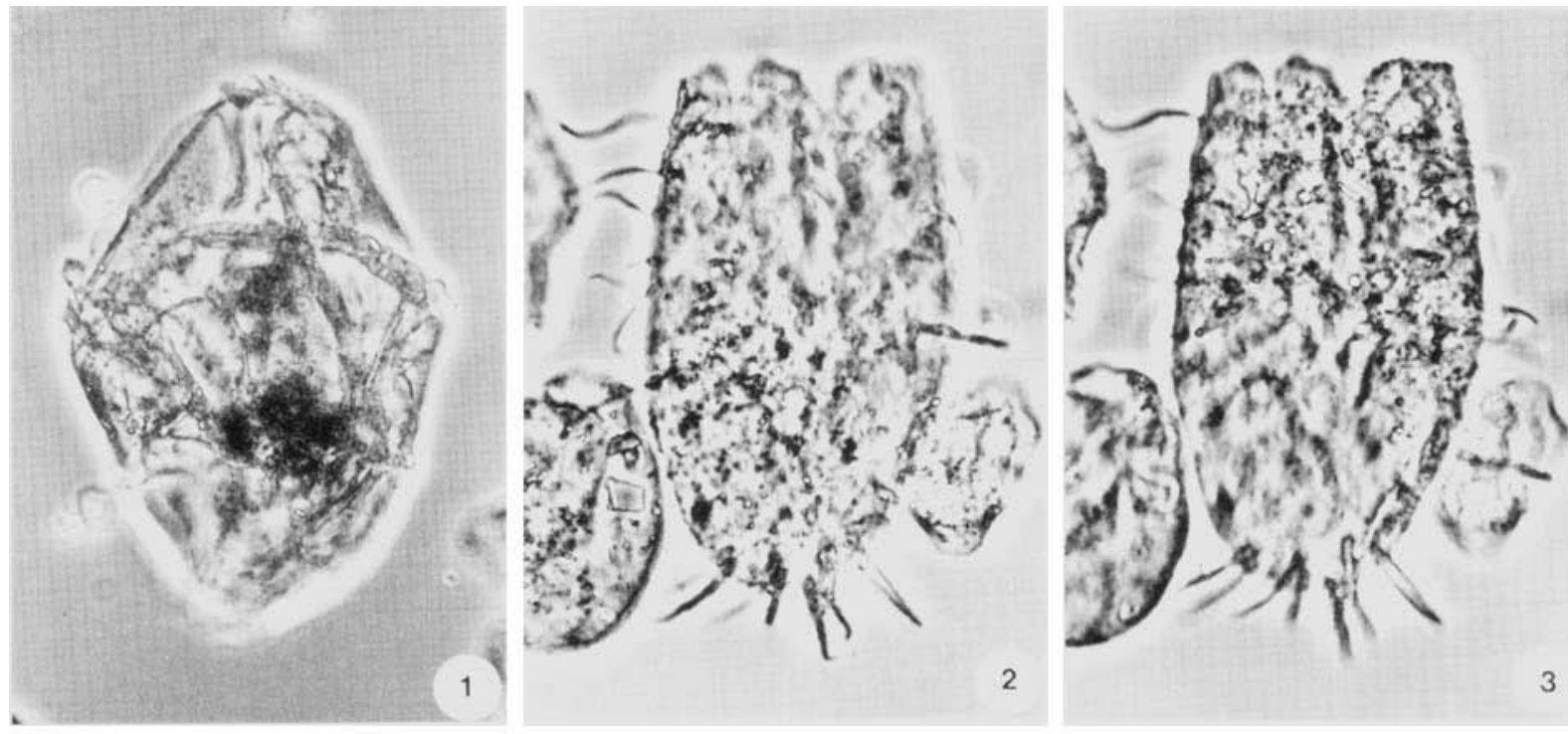

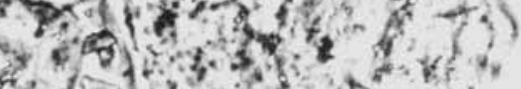

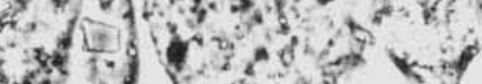
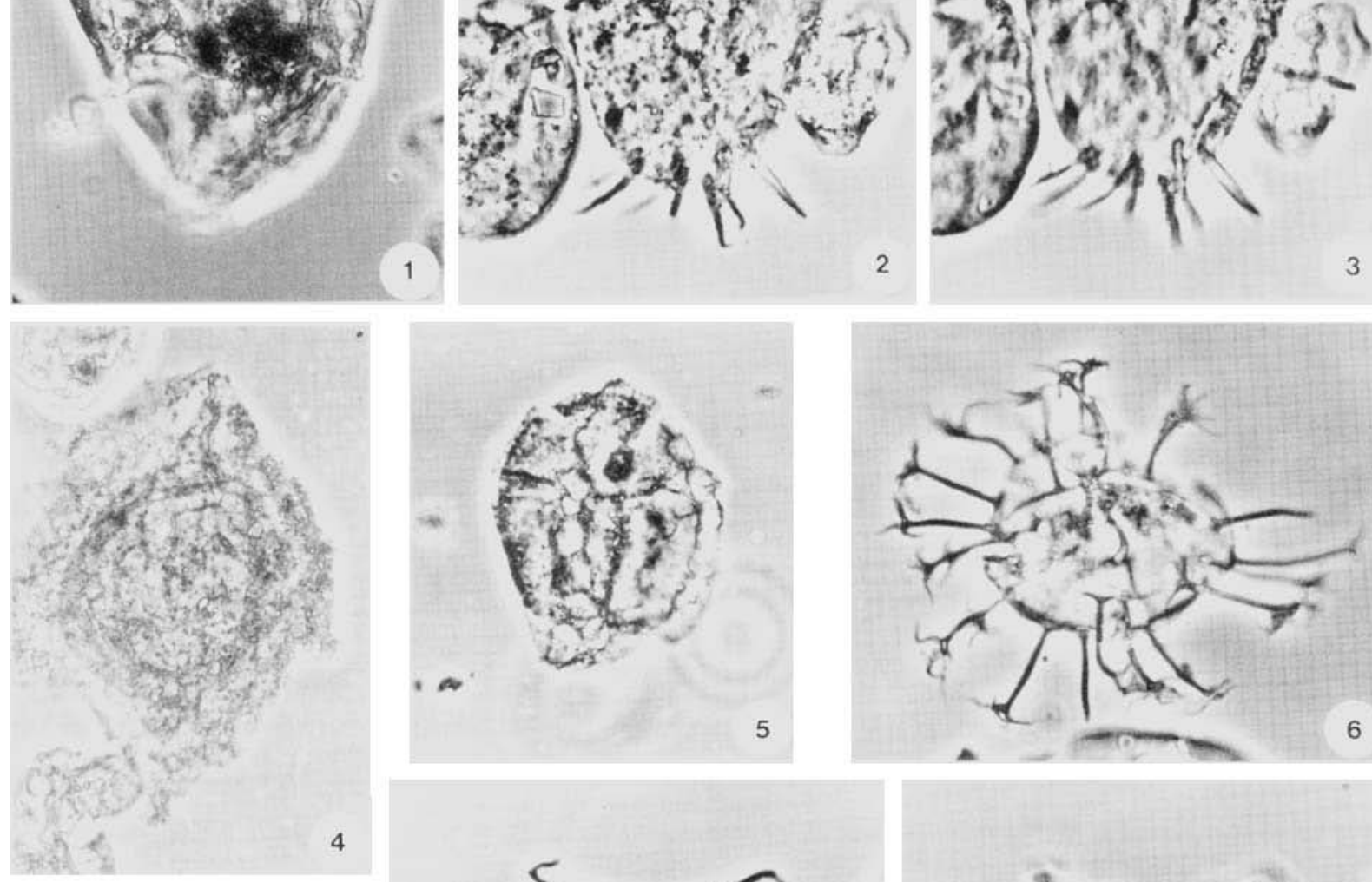

2
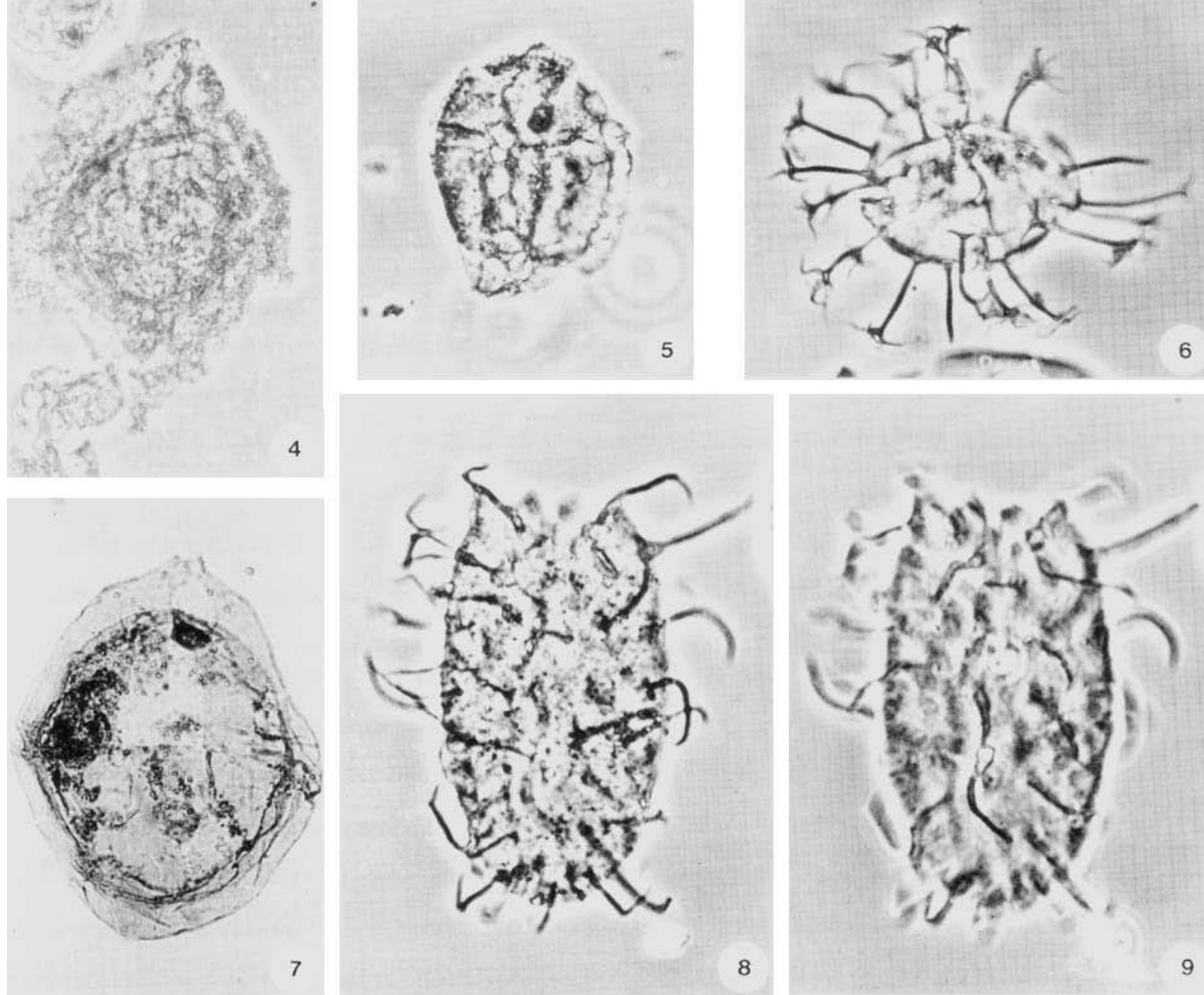

5

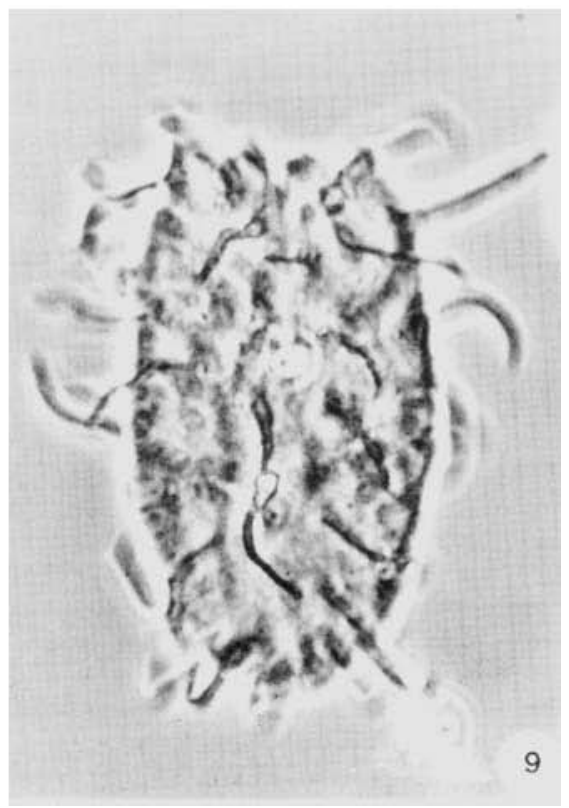



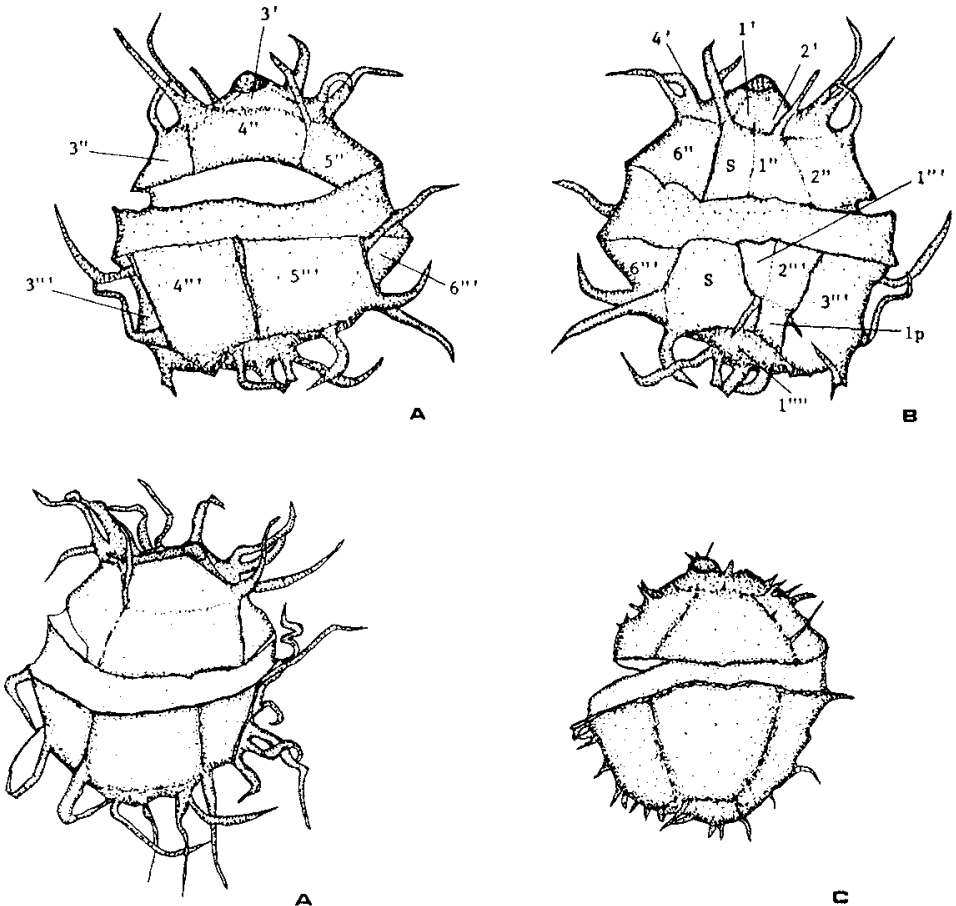

A

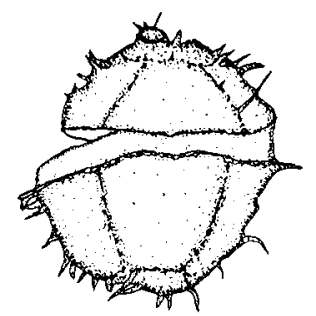

c
Fig. 6. Furzidinium sentum sp. nov. Holotype. Slide GMUS E2975/2, England Finder coordinate C33/1. A: ventral (upper) surface. B: dorsal (lower) surface. Magnification x1050.

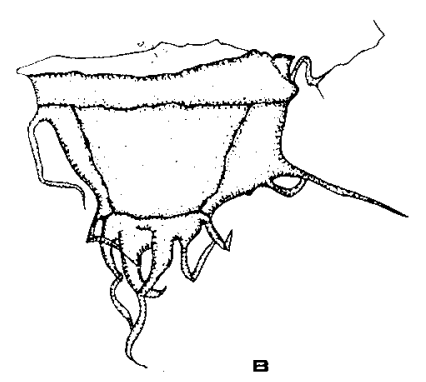

Fig. 7. Furzidinium sentum sp. nov. Paratype 1. Slide GMUS E2976/3, England Finder coordinate C32/0. Ventral (upper) surface. The operculum is slightly rotated. Magnification $x 1050$. B: Furzidinium sentum sp. nov. Paratype 2. Slide GMUS E2978/ 2, England Finder coordinate F43/2. Dorsal (upper) surface. The hypocyst. Magnification x 1050. C: Furzidinium sentum sp. nov. Paratype 3. Slide GMUS E2975/3, England Finder coordinate B43/1. Ventral (lower) surface. A form with shorter processes. Magnification $\times 1050$.

Explanation of Plate 3

Fig. 1. Cleistosphaeridium cf. polytrichum (Valensi 1947) Davey, Downie, Sarjeant and Williams 1969. Slide GMUS E3114/2, England Finder coordinate B40/ 4, MPK 9073. Lateral view, phase contrast, magnification circa $\times 600$.

Fig. 2. Endoscrinium galeritum (Deflandre 1938) Vozzhennikova 1967. Slide GMUS E3116/2, England Finder coordinate J29/4, MPK 9074. Dorso-ventral view, normal illumination, magnification circa $x 450$.

Fig. 3. Sentusidinium rioultii (Sarjeant 1968) Sarjeant and Stover 1978. Slide GMUS E3111/4, England Finder coordinate J47/2, MPK 9075. Dorso-ventral view, phase contrast, magnification circa $\times 600$.

Fig. 4. Furzidinium sentum sp. nov. Slide GMUS E2978/2, England Finder coordinate G46/1. Lateral view, phase contrast. A slightly rotated hypocyst with short processes showing the smooth cingular margin of the cingulum. Magnification circa $\times 500$.

Fig. 5. Furzidinium sentum sp. nov. Paratype 3. Slide GMUS E2975/3, England Finder coordinate B43/1. Lateral view, phase contrast, magnification circa x650. Fig. 6. Rigaudella aemula (Deflandre 1938) Below 1982. Slide GMUS E2974/1, England Finder coordinate H34/3. Phase contrast. A single isolated process with a hapto-process trabecula. Magnification circa $\times 600$.

Fig. 7. Tubotuberella egemenii (Gitmez 1970) Stover and Evitt 1978. Slide GMUS E3109/1, England Finder coordinate F37/4, MPK 9078. Dorso-ventral view, phase contrast, magnification circa $\times 600$.

Fig. 8. Dinopterygium dimorphum (Ioannides, Stavrinos and Downie 1976) Courtinat 1989. Slide GMUS E3113/2, England Finder coordinate V34/1, MPK 9079. Lateral view, phase contrast, magnification circa $\times 500$.

Fig. 9. Furzidinium sentum sp. nov. Paratype 2. Slide GMUS E2978/2, England Finder coordinate F43/2. Lateral view, phase contrast. The hypocyst showing the smooth cingular margin without a sulcal prominance. Magnification circa x750.

Fig. 10. Leptodinium ambiguum (Deflandre 1939) Sarjeant 1969. Slide GMUSE3113/1, England Finder coordinate E42/1, MPK 9080. Lateral view, phase contrast, magnification circa $\times 600$.

Fig. 11. Tubotuberella apatela (Cookson and Eisenack 1960) emend. Sarjeant 1984. Slide GMUS E3116/3, England Finder coordinate M37/2, MPK 9081. Dorsoventral view, phase contrast, magnification circa $\times 600$.

Fig. 12. Tubotuberella apatela (Cookson and Eisenack 1960) emend. Sarjeant 1984. Slide GMUS E2978/1, England Finder coordinate G35/0. Dorso-ventral view, phase contrast, magnification circa $\times 600$.

Fig. 13. Systematophora orbifera Klement 1960. Slide GMUS E3109/1, England Finder coordinate B33/3, MPK 9083. Dorso-ventral view, phase contrast, magnification circa $x 600$. 

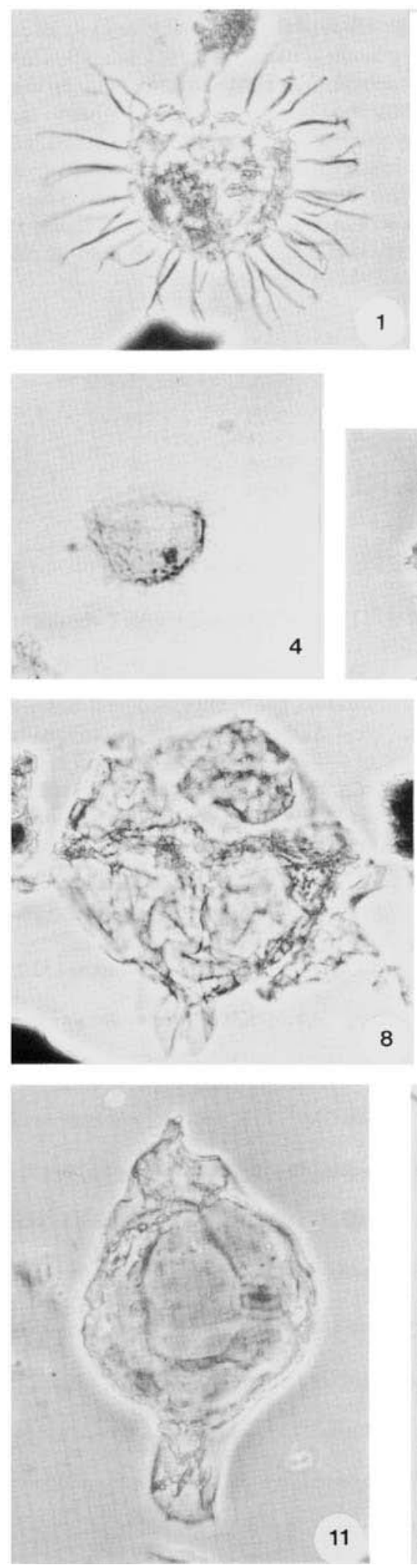

8
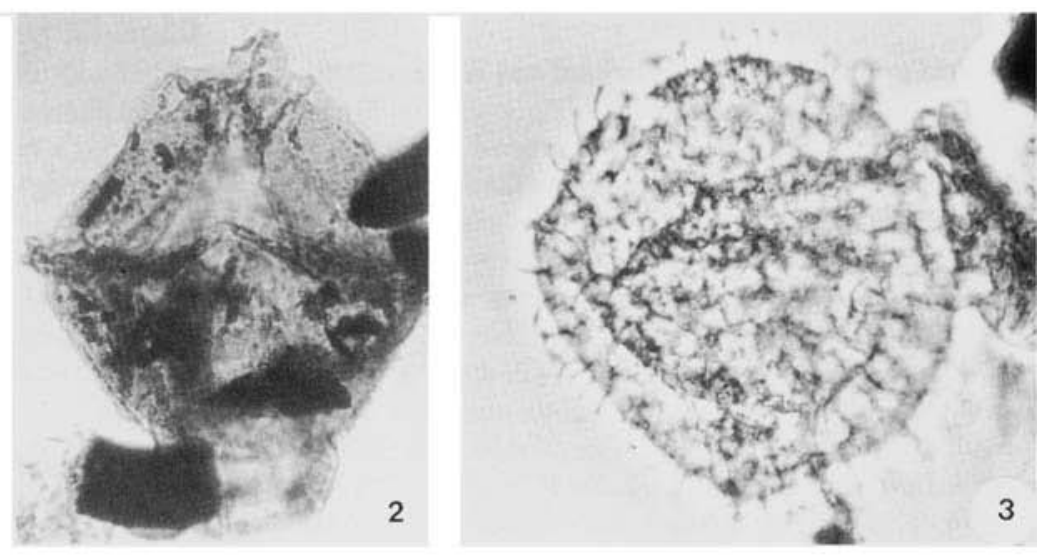

3
4

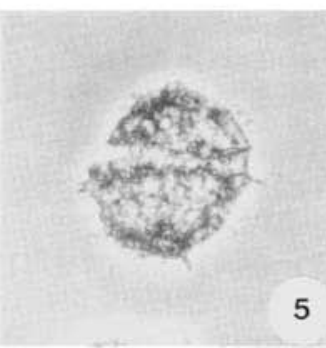

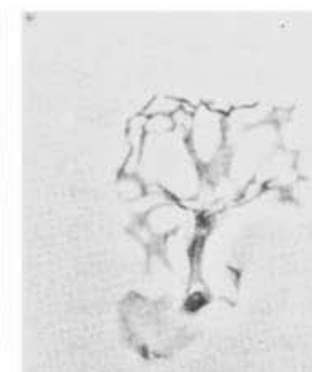

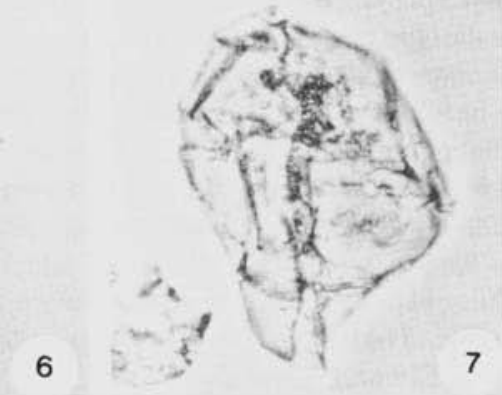

7

9
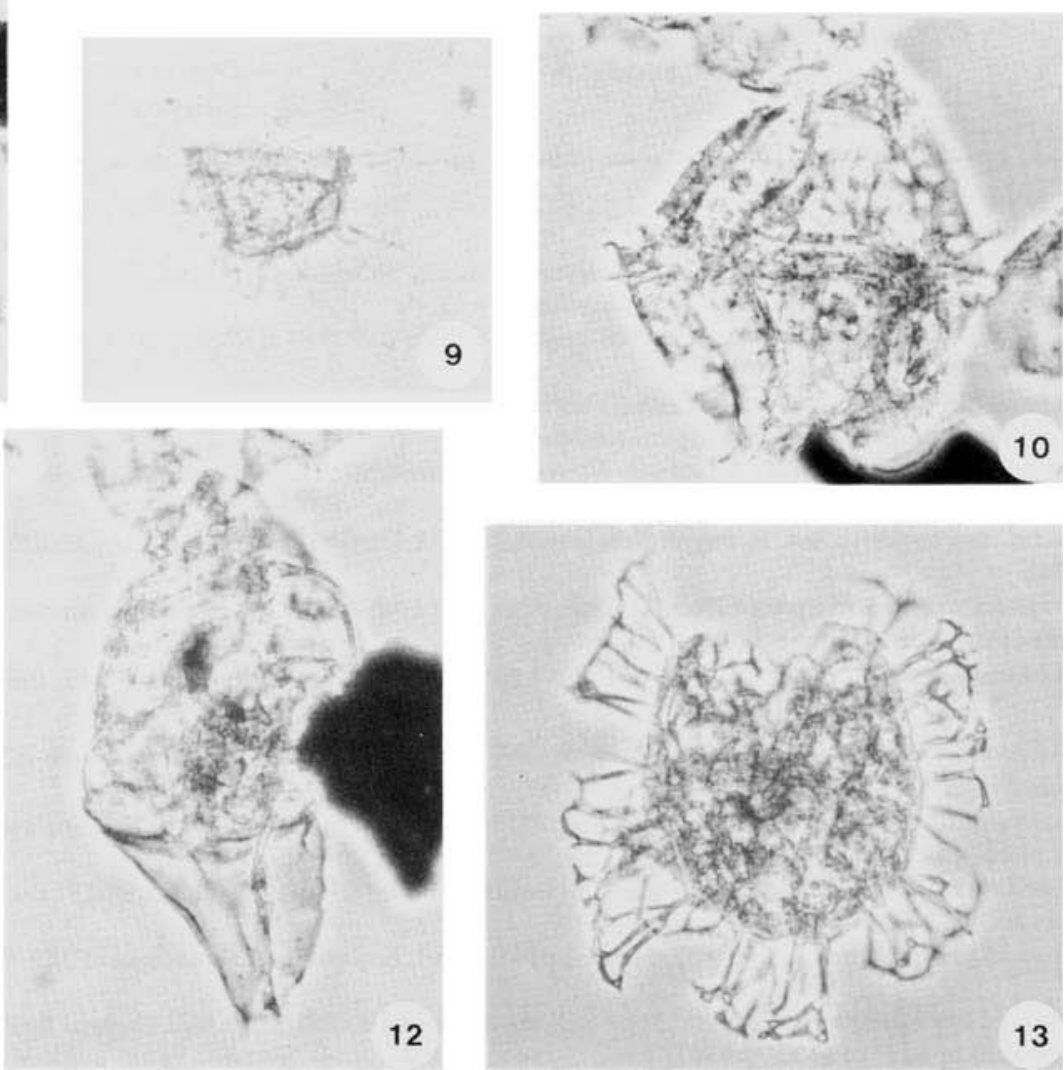
include the top of the Oxfordian of Skye. Pocock did not record in detail the strata from which he found his specimen.

\section{Prolixosphaeridium Davey, Downie, Sarjeant and Williams 1966; emend. Davey 1969}

Remarks. The type species was originally erected by Deflandre (1937) as a sub species of Hystrichosphaeridium xanthiopyxides (O. Wetzel 1933) Deflandre 1937, with a very brief diagnosis... "An individual, ellipsoidal, punctate, covered with many short spines" (translation from French). No dimensions were given and there is not a photograph in the paper; however, a scale line diagram was presented and it can be used to estimate the size of the cyst. Central body length, with archeopyle circa $40 \mu \mathrm{m}$, breadth circa $20 \mu \mathrm{m}$, process length $4-7 \mu \mathrm{m}$, number of processes $80-100$. This broadly agrees with the dimehsions given by Sarjeant (1978, p. 23). Davey \& Verdier (1974, p. 636-7) designated the original type species, Prolixosphaeridium deirense Davey, Downie, Sarjeant \& Williams 1969 as a junior synonym of $P$. parvispinum but did not redescribe or illustrate the type species. A restudy of the original type specimen of $P$. parvispinum and the designation of paratypes is urgently required, if it is to be of use as the type species of Prolixosphaeridium.

The difference between Prolixosphaeridium and Sentusidinium Sarjeant \& Stover 1978 is that the former has non tabulate processes arranged in lines extending around the ellipsoidal body of the cyst. This has lead to problems with species which have many small processes, not arranged in a discernable pattern, and only somewhat elongate central bodies; for example Prolixosphaeridium capitatum (Cookson \& Eisenack 1960) Singh 1971.

Prolixosphaeridium floccum sp. nov.

(Pl. 2, figs. 2-3, 8-9; text-fig. 8)
Derivation of name. Latin, floccus, tuft, referring to the antapical grouping of processes.

Diagnosis. Elongate ellipsoidal proximochorate cyst, its surface covered with coarse granules. Processes sparse (circa. 40-50 on cysts without attached archeopyles) flexible and fairly long (up to a third of the cyst's breadth); they can be flared at their bases, tapering distally, straight, synodal or bent at right angles (especially the processes near the antapex). Process tips are closed, typically acuminate, rarely blunt. Tabulation indicated by the six plates of the archeopyle and on well preserved specimens a sulcus is discernable. A faint cingulum may also be indicated by two lines of enlarged granules between which is an area devoid of processes.

$\begin{array}{llll}\text { |Dimensions. }(\mu \mathrm{m}) & & & \\ & \text { Skye } & \text { Holotype } & \text { Paratype } \\ \text { body length (no operc.) } & 45-52 & 46 & 47 \\ \text { body breadth c } & 25-28 & 28 & 27 \\ \text { process length } & 13-17 & 11 & 13 \\ \text { number of processes } & 40-60 & 40 & 48 \\ \text { number measured (recorded) } & 8(12) & & \end{array}$

\section{Type material.}

Holotype; slide GMUS E3115/2, England Finder Coordinate N43/1; Plate 2, Figures 1-2; Text-figure 8.

Paratype 1; slide GMUS E3115/2, England Finder Coordinate U46/ 1; Plate 2, Figures 8-9.

Occurrence. Found in the Amoeboceras rosenkrantzi zone of the Late Oxfordian, Upper Jurassic, Isle of Skye, Scotland. Slides stored at the British Geological Survey, Keyworth, Nottinghamshire. Remarks. Specimens of this species were only found in the Skye assemblage. It was initially difficult to distinguish this species from Prolixosphaeridium parvispinum. The low number of processes, their clustering near the antapex accompanied by the lack of distinct

Explanation of Plate 4

Fig. 1. Stephanelytron scarburghense Sarjeant 1961a emend. Stover, 34 Sarjeant and Drugg 1977. Slide GMUS E3113/2, England Finder coordinate L32/2, MPK 9084. Dorso-ventral view, phase contrast, magnification circa $\times 950$.

Fig. 2. Polygonifera bavarica (Lund and Ecke 1988) comb. nov. Slide GMUS E3115/3, England Finder coordinate E38/1, MPK 9085. Dorso-ventral view, normal illumination, magnification circa $x 600$.

Fig. 3. Aldorfia dictyota subsp. osmingtonensis (Gitmez 1970) Jan du Chene et al., 1986. Slide GMUS E3109/2, England Finder coordinate S42/0, MPK 9086. Lateral view, phase contrast, magnification circa $\times 650$.

Fig. 4. Sirmiodinium grossii Alberti 1961 emend. Warren 1973. Slide GMUS E3113/2, England Finder coordinate G38/1, MPK 9087. Dorso-ventral view, phase contrast, magnification circa $\times 750$.

Fig. 5. Furzidinium sentum sp. nov. Holotype. Slide GMUS E2975/2, England Finder coordinate C33/1. Dorso-ventral view, nemaski illumination, magnification circa $\times 1050$.

Fig. 6. Korystocysta qochtii (Sarjeant 1976a) Woollam 1983. Slide GMUS E3112/2, England Finder coordinate D45/0, MPK 9088. Oblique lateral view, normal illumination, magnification circa $\times 600$.

Fig. 7. Sirmiodiniopsis orbis Drugg 1978. Slide GMUS E2976/1, England Finder coordinate D29/1. Dorso-ventral view, phase contrast, magnification circa $\mathrm{x} 650$.

Fig. 8. Ellipsoidictium cinctum Klement 1960. Slide GMUS E3113/1, England Finder coordinate N27/2, MPK 9090. Dorso-ventral view, phase contrast, magnification circa $\times 600$

Fig.9. Systematophora valensii (Sarjeant 1960) Downie and Sarjeant 1964. Slide GMUS E31 1.3/2, England Finder coordinate F37/4, MPK 9091. ?Antapical view, normal illumination, magnification circa $\mathbf{4 5 0}$.

Fig. 10. Barbatacysta verrucosa (Sarjeant 1968) Courtinat 1989. Slide GMUS E2974/3, England Finder coordinate B33/1. Dorso-ventral view, phase contrast, magnification circa $\times 600$.

Fig. 11. Atopodinium prostatum Drugg 1978. Slide GMUS E2978/1, England Finder coordinates F32/3. Dorso-ventral view, phase contrast, magnification circa $\mathrm{x} 400$.

Fig. 12. Heslertonia teichophera (Sarjeant 1961a) Sarjeant 1976b. Slide GMUS E3116/3, England Finder coordinate L43/0, MPK 9094. ?Lateral view, phase contrast, magnification circa x650.

Fig. 13. Chytroeisphaeridia chytroeides (Sarjeant 1962) emend. Davey 1979. Slide GMUS E3111/4, England Finder coordinate E36/2, MPK 9095. Lateral view, normal illumination, magnification circa $\times 600$. 

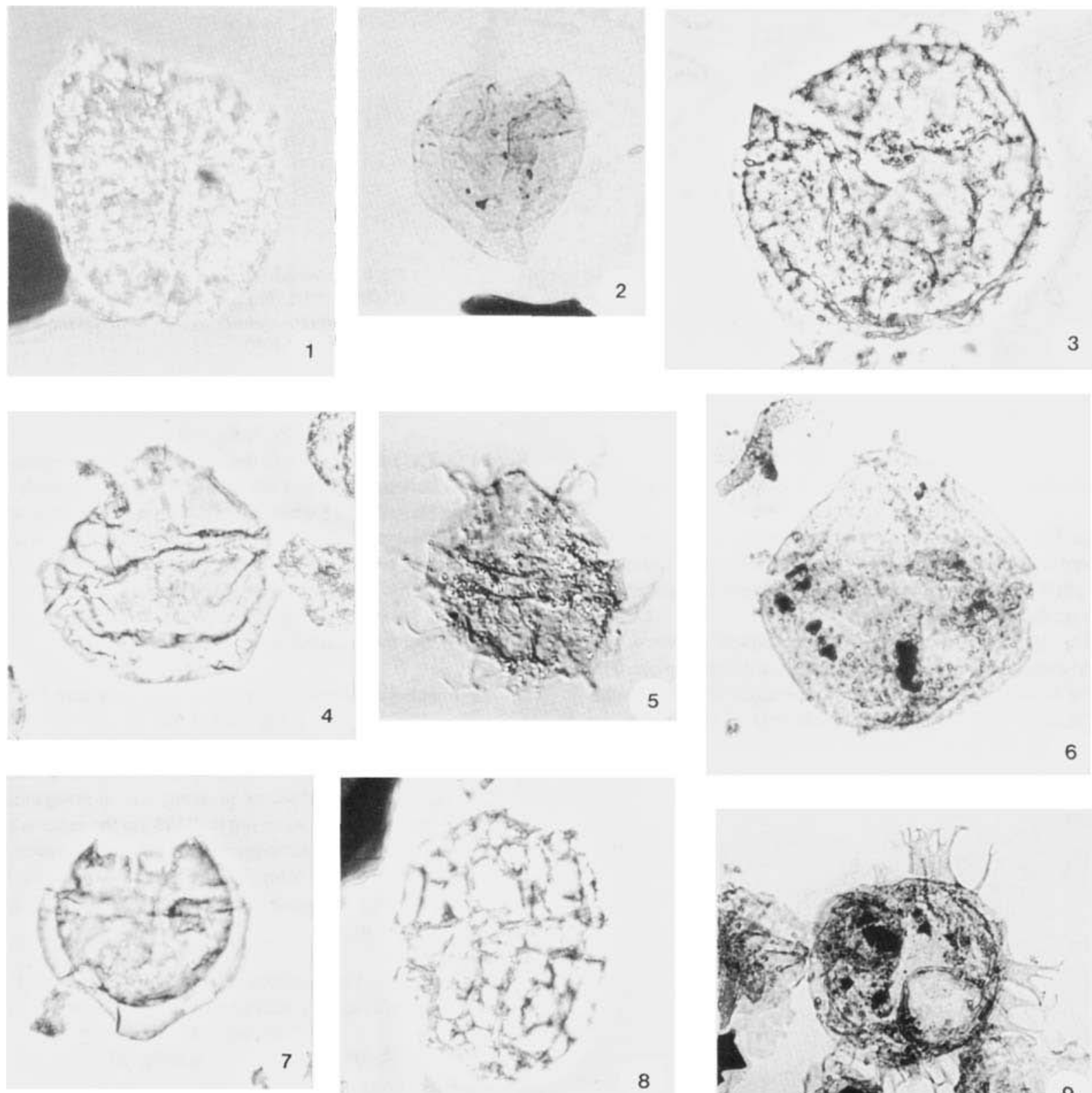

8

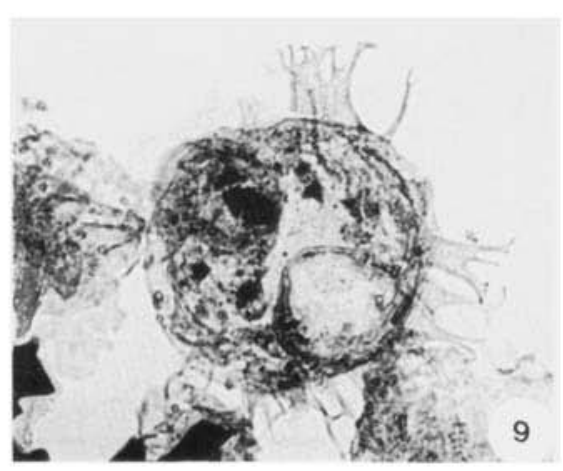

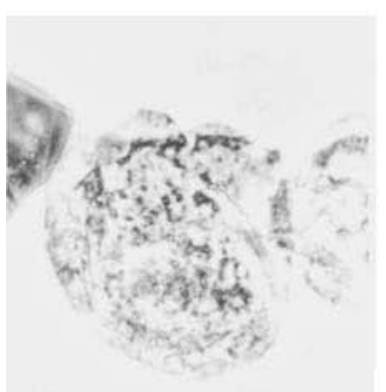

10

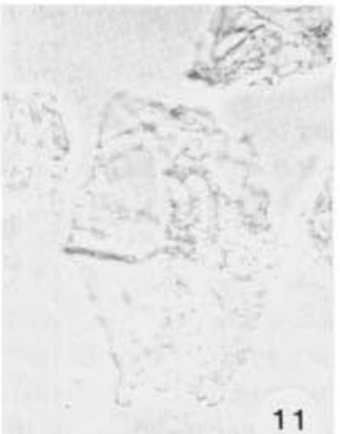

11
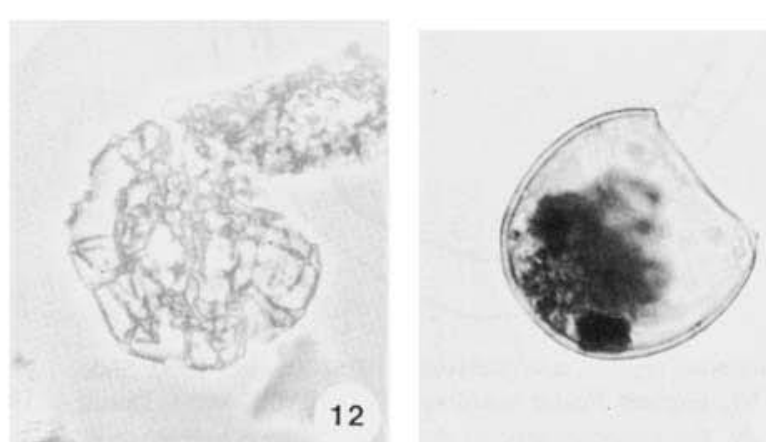

13 


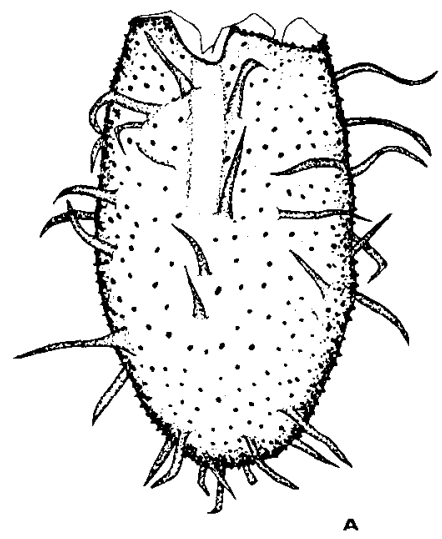

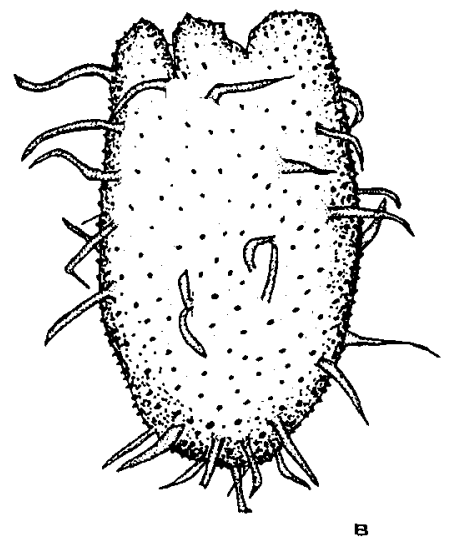

$\mathbf{B}$
Fig. 8. Prolixosphaeridium floccum $\mathrm{sp}$, nov. Holotype. Slide GMUS 3115/2, England Finder coordinate N43/1, MPK 9052. A: ventral (lower) surface. B: dorsal (upper) surface. Magnification x 1050 .

\section{Systematophora Klement 1960 \\ Systematophora orbifera Klement 1960}

(Pl. 3, fig. 13)

Remarks. The differentiation of this species from Adnatosphaeridium caulleryi (Deflandre 1938) is not simple, despite the emendation and remarks in Stancliffe \& Sarjeant (1990). Systematophora orbifera has well organized processes forming distal rings while, at its most developed, A. caulleryi has major process clusters only on the precingular, post-cingular and antapical plates. It is apparent that the two species are closely related morphologically with $A$. caulleryi possibly being the ancestral form.

\section{Systematophora valensii (Sarjeant 1960) Sarjeant 1961b}

(P1. 1, fig. 9; P1. 4, fig. 9)

Remarks This species appears closelyr elated to Systematophora areolata Klement 1960 and Systematophora penicillata (Ehrenberg 1843 ex 1854) Sarjeant 1980 and probably has an intergradation of morphological features. The raised wall linking the process bases of a cluster and the two or more stages of distal branching of each process distinguisyh the species from $S$. areolata. S. penicillata has the presence of paired processes marking the cingulum which is not the case with $S$. valensii.

Tubotuberella Vozzhennikova 1967; emend. Sarjeant 1982

Tubotyuberella apatela (Cookson \& Eisenack 1960); emend. Sarjeant 1984

Dimensions $(\mu \mathrm{m})$

(Pl. 3, figs. 11-12; text-fig. 10)

Total length

total breadth

horn length

inner body length

inner body breadth

inner body horn

hypo. length $A 1$

hypo. length A2

hypo. width Ant 1

hypo. width Ant 2

hypo. width Ant 3

hypo flange width

number measured

(recorded)

$\begin{array}{ll}\text { Skye } & \text { Southern } \\ 64-98 & 79-85 \\ 31-52 & 45-46 \\ 3-8 & 0-2 \\ 41-61 & 51-52 \\ 26-52 & 45-46 \\ 0-1 & \\ 21-36 & 16-33 \\ 13-33 & 15-27 \\ 18-38 & 28-33 \\ 16-25 & 23-27 \\ 10-17 & 10-13 \\ 8-16 & 13-18 \\ 7(11) & 2(3)\end{array}$
$\times 2100$.

Fig. 9. Scriniodinium crystallinum (Deflandre 1938) Klement 1960. Slide GMUS E3112/1, England Finder coordinate G30/0, MPK 9053. Dorsal (lower) surface. The secondary opening above the 3" plate is well shown as 

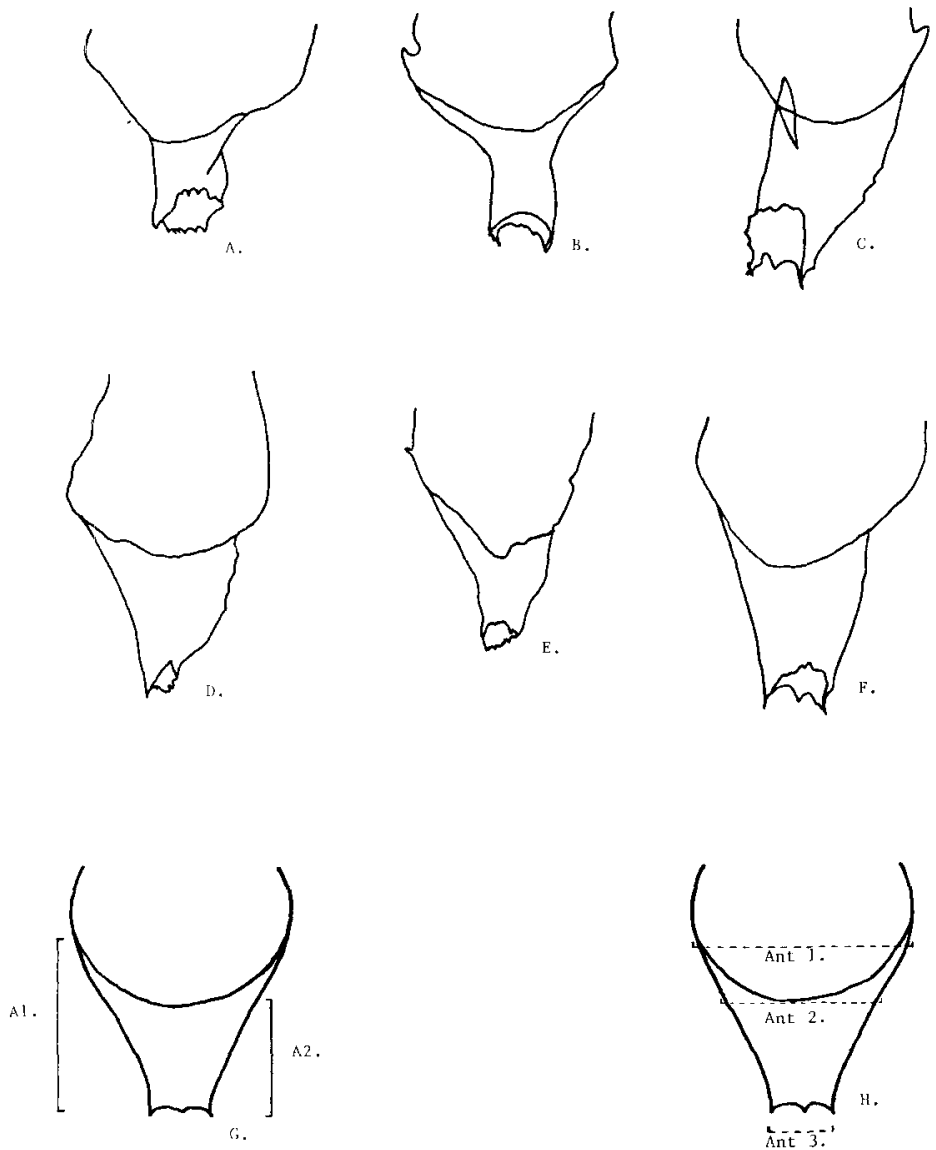

Fig. $10 \mathrm{~A}-\mathrm{F}$. Variation in the shape of the antapical extension of the periphragm of Tubotuberella apatela (Cookson \& Eisenack 1960). All are camera lucida drawings at a magnification of circa $440 \mathrm{x} . \mathrm{A}$ : Slide GMUS E3116/2, England Finder coordinate M37/2, MPK 9052. B: Slide GMUS E3112/2, England Finder coordinate L35/1, MPK 9055. C: Slide GMUS E3113/1, England Finder coordinate F33/1, MPK 9056. D: Slide GMUS E2978/1, England Finder coordinate G35/0. E: Slide GMUS E3116/3, England Finder coordinate J43/3, MPK 9058. F: Slide GMUS E2976/1, England Finder coordinate $\mathrm{L} 41 / 1$. G: The two length measurements of the antapical region drawn on a stylised representation of $T$. apatela. $\mathrm{H}$ : The three width measurements of the antapical region on a stylised representation of $T$. apatela.
Remarks. Sarjeant (1982, p.42), following his emended diagnosis of this species, notes in a discussion section the difference between Tubotuberella apatela and Tubotuberella dangeardii (Sarjeant 1968) Stover and Evitt 1978. The former has a more elongate outline and a hypopericoel (hypo.) whose length is equal to or slightly greater than its breadth. The width of a hypopericoel is difficult to measure as it varies along its length. The length of a hypopericoel was also not classified in the paper and this causes problems if the separation of the two walls of the cyst extends a long way up the endoblast towards the cingulum. Text-figure 10 shows the suggested measurements used in the present study: the distance from the antapical tip of the inner body (length A 2) versus the width (Ant 2) of the hypopericoel at the antapical tip of the inner body, for the specific differentiation. This removes the ambiguity of the classification and also minimizes the variability of laboratory processing which can alter the amount of wall to wall contact. This effect was discussed and illustrated by Schrank (1988) in a paper on the classification of Cretaceous Peridinioid species but it is probable that all two and three walled cysts behave the same way.

\section{DISCUSSION OF THE ASSEMBLAGES STUDIED}

The two sequences described contain diverse assemblages which are recorded in Text-figures 11-12. The study recorded 46 species of dinoflagellate cysts which have been assigned to 39 genera. The Skye sequence has 32 genera and 35 species of dinoflagellate cysts and the southern Dorset sequence has 32 genera and 30 species of dinoflagellate cysts.

There have been many published and unpublished papers on the biostratigraphy of British sequences of Oxfordian Age, and detailed analysis of all these reports is beyond the scope of the present study. However, Williams \& Bujak (1985) summarized the important dinocyst occurrences, listing 21 species of dinoflagellate cysts which have biostratigraphic significance in the Late Oxfordian. Of these, this study found in the Skye sequence Pareodinia ceratophora, Ellipsoidictyum cinctum, Gonyaulacysta jurassica, Tubotuberella apatela, Sirmiodinium grossii, and Scriniodinium crystallinum. For the Early Oxfordian, Williams \& Bujak (1985) listed 32 dinoflagellate cyst species of biostratigraphic significance of which Riqaudella aemula, Pareodinia ceratophora, Nannoceratopsis pellucida, Sirmiodiniopsis orbis, Gonyaulacysta jurassica, Netrelytron stegastum, Tubotuberella apatela, Sirmiodinium grossii, Stephanelytron spp., Atopodinium prostatum and Scriniodinium crystallinum were found in the southern Dorset sequence. A search of the other recorded species in this study found only one anomalous occurrence (as outlined by Williams \& Bujak, 1985), Senoniasphaera jurassica, which has been previously reported to have its first occurrence in the Early Kimmeridgian. In this study the sole recorded specimen was found in the Early Oxfordian; further examples have to be recorded before an extension in the range of the species can be contemplated. 
SKYE

Aldorphia dictyota esmingtonensis Atopedinium prostatum Acopodinium spp.

Barbatacysta cf. brexispinosa

Barbatacysta creberbarbaca

Barbatacysta verrucesa

Chlamydophorella spp.

Chytroeisphaeridia chytroeldes

Chytroeisphaeridia spp.

cleistosphaeridium ehrenbergii

cleistosphaeridium sarmentum

cleistosphaeridium? tribuliferum

Cleistosphaeridium spp.

cryptarchaeadinium granuligerum

stentadodindum renellum

Ctenidedinium epp.

Dinopterygium dimorphum

Ellipsatdiatyum clnatum

Ellipsoidictyum spp.

Endoscrinium galeritum

Endoscrinium Luridum

Eschariophaeridla pecockll

Escharisphaeridia pgilata

Escharisphaeridla opp.

Fromea tornatilia

Eurzidinium sentum

Gonyaulacysta jurassica jurassica

Heslertonia teichophera

Keryarecyata gochtii

Leptodintum ambigum

Leptodinium freakei.

Leptodinium spp.

Liesbergia scarburghensis

Lithodinia spp.

Melourogonyaulax spp.

Nannoceratopgle pellucida

Netrelytron stegastum

Paragenyaulacysta spp.

Pareodinla ceratophora

Pareodinia epp.

Perisselasphaeridium spp.

Pilosidinium echinatum

Pelygontera bavarica

Prolixosphaertdium fleccum

Prolixosphaeridium parxispinum

Prolixesphaeriditum spp.

Bhynchodiniapeis sladophora

Bhynchodiniopsis spp.

Rigaudella aemula

Bigaudella spp.

Scriniodinium crystallinum

Scriniodinium spp.

Senoniasphaera juragsica

Sentusidinium rioultii

Sentusidinium villersense

Sentusidinium spp.

Sirmiodiniopsia erbis

Sirmiodiniun grossij

Sirmiodinium spp.

Stephanelytron scarburghensis

Stephanelytron spp.

Surculosphaeridium cribrotubiferum

Surculosphaeridium spp.

Systematophora erbifer

Systematophora valensij

Systematophera spp.

Tubotuberella apatela

Tubotuberella egemenii

Tubotuberella spp.

$P=$ present; $1-5$ specimens

Ca cormon, 6-20 specimens

$A=$ abundant: $21+$ opecimens

Fig. 11. Distribution chart of the dinoflagellate cysts found in the Skye, Scotland sequence. The samples are located by their last two digits. 
Oxfordian dinoflagellates from Skye and Dorset

\section{ALPHABETICAL LISTING OF DINOFLAGELLATE CYSTS}

\section{SOUTH DORSET}

Aldorphia dictyota osmingtonensis Atopodinium prostatum

Atopodinium spp.

Barbatacysta c $f$. brevispinosa

Barbatacysta creberbarbata

Barbatacysta vexuucosa

chlamydophorella epp.

chytroeisphaeridia chytroeides

Chytroeisphaeridia opp.

Clelotosphaerldium ehrenbergid

cleistosphaeridium sarmentum

cleistosphaeridium? tribuliferum

Cleistosphaeridium spp.

cryptarchaeodinium granuligerum

ctenidodinium tenellum

Ctenidodinium spp.

Dinopterygium dimocphum

Ellipsoidictyum cinctum

Ellipsoidictyum spp.

Endoacidulun galeriliu

Endoscrinium Luridum

Eschartaphaeridia pocockij

Eacluarlophaecidia pallata

Escharisphaeridia spp.

Fromea tornatilis

Furzidinium sentum

Gonyaulacysta jurassica jurassica

Heslertonia teichophera

Koryatocyata gochtil

Leptodinium anbiguum

Leptedinium freakei

Leptodinium spp.

Liesbergia scarburghens is

Whthodinia apo.

Mejeurogenyaulax spp

Nannoceratopsis pellucida

Netrelytron stegastum

Paragonyaulacysta spp.

Pareodinia ceratophora

Rareodinia spp.

Perigselasphaeridium spp.

pilesidinium echinatum

Polygonifera bavarica

Prolixosphaeridium floccum

Prolixosphaeridium paryispinum

Prolixesphaexidium opp.

Rhynchodintopgis cladophora

Rhynchedinlopsis spp.

Rigaudella aemula

Rigaudella spp.

Scriniodiniuro crystallinum

Scriniodinium spp.

Senoniasphaera jurassica

Sentusidinium rioulti

Sentualdinium villersense

Sentusidinium spp.

Sirmiodiniopsis orbis

Sirmiodinium grossii

Simiodinium spp.

stephanelytron scarburghensis

Stephanelytion spp.

Surculosphaeridium cribrotubirerum

Surculosphaeridium spp.

Systemataphora orbifera

Syotcmatophora valenait

Systematophora spp.

Tubotuberella apatela

Tubotuberella egemenil

Tubetuberella spp.

$P=$ present, $1-5$ specimens

$C=$ conmon; $6-20$ specimens

$A=$ abunclant : $21+$ specimens

\begin{tabular}{|c|c|c|c|c|c|}
\hline 74 & 75 & 76 & 77 & 78 & 79 \\
\hline . & . & . & - & . & . \\
\hline . & . & . & - & P & . \\
\hline . & . & . & . & • & - \\
\hline $\mathbf{P}$ & $P$ & $\mathbf{P}$ & $\mathbf{P}$ & $P$ & $P$ \\
\hline C & . & . & . & . & • \\
\hline $\mathbf{P}$ & . & . & - & - & . \\
\hline . & $\mathbf{P}$ & . & . & - & . \\
\hline $\mathbf{P}$ & $\mathbf{P}$ & $\mathbf{P}$ & . & , & . \\
\hline $\mathbf{P}$ & $\mathbf{P}$ & . & . & . & . \\
\hline . & . & . & $\mathbf{P}$ & . & . \\
\hline . & . & . & . & . & . \\
\hline . & . & $\mathbf{P}$ & $\mathbf{P}$ & . & $\mathbf{P}$ \\
\hline $\mathbf{P}$ & . & $\mathbf{p}$ & . & . & . \\
\hline . & . & . & . & . & • \\
\hline . & . & . & $\mathbf{P}$ & . & . \\
\hline . & $\mathbf{P}$ & . & $\mathbf{P}$ & C & . \\
\hline $\mathbf{P}$ & $\mathbf{P}$ & . & . & . & . \\
\hline . & . & ' & • & . & . \\
\hline $\mathbf{P}$ & . & . & • & . & • \\
\hline . & . & · & . & . & . \\
\hline . & $\dot{0}$ & $\therefore$ & i & : & • \\
\hline $\mathbf{P}$ & $\mathbf{P}$ & $\mathbf{P}$ & $\mathbf{P}$ & $\mathbf{P}$ & $\dot{\mathbf{P}}$ \\
\hline P & $\cdot$ & $\mathbf{P}$ & $\dot{p}$ &. & $\begin{array}{l}\mathbf{P} \\
\mathbf{P}\end{array}$ \\
\hline $\begin{array}{l}\mathbf{P} \\
\text {. }\end{array}$ & $\dot{.}$ & $\begin{array}{l}\mathbf{P} \\
\mathbf{P}\end{array}$ & P & $\dot{P}$ & $\mathbf{P}$ \\
\hline$F$ & $\mathrm{C}$ & p & . & . & . \\
\hline C & $\mathbf{P}$ & P & $\mathbf{P}$ & P & $\mathbf{P}$ \\
\hline . & . & . & . & . & . \\
\hline . & - & . & . & . & . \\
\hline . & , & . & . & . & . \\
\hline - & $\cdot$ & $\cdot$ & . & . & • \\
\hline $\mathbf{P}$ & • & • & . & . & • \\
\hline $\mathbf{P}$ & . & . & . & - & - \\
\hline $\mathbf{P}$ & . & . & . & . & . \\
\hline $\mathbf{P}$ & P & $\mathbf{P}$ & $\mathbf{P}$ & - & . \\
\hline $\mathbf{P}$ & P & . & $\mathbf{P}$ & . & : \\
\hline . & - & $\dot{0}$ & . & • & $\mathbf{P}$ \\
\hline . & $\mathbf{P}$ & $\mathbf{P}$ & : & : & : \\
\hline $\mathbf{P}$ & P & $\mathbf{P}$ & $\mathbf{P}$ & $\mathrm{P}$ & $\mathbf{P}$ \\
\hline $\mathbf{P}$ & C & $\mathbf{p}$ & $\mathbf{P}$ & . & " \\
\hline i & i & $\dot{0}$ & : & i & : \\
\hline $\mathbf{P}$ & $\mathbf{P}$ & $\mathbf{P}$ & $\mathbf{P}$ & $\mathbf{P}$ & $\mathbf{P}$ \\
\hline • & • & . & . & . & $\cdot$ \\
\hline . & . & $\cdot$ & . & . & • \\
\hline $\mathbf{P}$ & $\mathbf{P}$ & . & , & . & . \\
\hline $\mathbf{P}$ & $\mathbf{P}$ & $\mathbf{P}$ & . & . & . \\
\hline C & $\mathbf{P}$ & . & $\mathbf{P}$ & $\mathbf{P}$ & • \\
\hline . & $\cdot$ & $\mathbf{P}$ & . & : & . \\
\hline C & $\cdot$ & . & $\mathbf{P}$ & C & . \\
\hline : & . & $\mathbf{P}$ & . & . & • \\
\hline $\mathbf{P}$ & $\mathbf{P}$ & . & : & $\mathrm{P}$ & . \\
\hline i & . & • & $P$ & - & $\cdot$ \\
\hline $\mathbf{P}$ & · & . & • & • & • \\
\hline . & $\cdot$ & . & . & - & $\cdot$ \\
\hline : & $\dot{0}$ & i & . & : & : \\
\hline A & C & $P$ & C & $\mathbf{P}$ & C \\
\hline . & : & $\mathbf{P}$ & - & . & \\
\hline P & $\mathbf{P}$ & P & . & . & \\
\hline . & P & . & P & . & \\
\hline . & $\dot{0}$ & $\dot{0}$ & $:$ & $\cdot$ & \\
\hline . & $\mathbf{P}$ & $\mathbf{P}$ & P & . & \\
\hline • & $\mathbf{P}$ & • & • & • & \\
\hline • & $\mathbf{P}$ & - & . & • & \\
\hline in & • & $\cdot$ & i & : & \\
\hline p & $\cdot$ & $\dot{p}$ & F & $\dot{p}$ & \\
\hline$\cdot$ & • & $\begin{array}{l}P \\
p\end{array}$ & $\mathrm{P}$ & $\begin{array}{l}\mathbf{P} \\
\mathbf{P}\end{array}$ & \\
\hline$\dot{\mathbf{P}}$ & $\dot{.}$ & P & 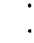 & . & \\
\hline & & & & & \\
\hline
\end{tabular}

Fig. 12. Distribution chart of the dinoflagellate cysts found in the southern Dorset, England sequence. The samples are located by their last two digits. 
The paleoenvironment of deposition can be inferred from the assemblages already described. Both sequences have a high diversity of dinoflagellate cysts which, according to Williams and Sarjeant (1967, p. 393) indicates an open marine environment with normal levels of salinity. The chorate cysts only form a small part (generally less than $7 \%$ ) of the assemblages which is the norm in 2 other studies of Oxfordian dinoflagellate cysts (Sarjeant 1968, tab. 1). In a study of Cenomanian marine palynomorphs, Davey (1970, p. 395) found that cavate dinoflagellate cysts dominate in cool water while in warm water they are rare. Though these cysts are peridinacean forms, it is thought that gonyaulacean cavate forms have such a similar overall morphology that comparable reationships to water temperature can be tentatively inferred. Davey also suggested that chorate cysts should be more abundant in warm seas due to their ability to sink in the less dense water. In the present study, cavate and chorate cysts are always a minor component of the assemblages. However, no paleoenvironmental conclusions can be made as most Upper Jurassic assemblages are dominated by proximate cysts. This is, no doubt, influenced by the evolution of cyst morphology which initially was dominated by proximate cysts in the Triassic and Lower Jurassic. Cavate and chorate cysts only started to become the dominant morphologies in later assemblages such as those from Cretaceous sediments.

This evidence indicates that the two sequences are both from sediments deposited in fully marine environments which were similar, though not identical. The marine environment was not of excessively high energy, and had no extremes of salinity or temperature which could have inhibited the growth of marine palynomorphs or the preservation of their cysts upon deposition in the sediment. The large number of terrestrial pollen and spores found (though not subjects of detailed study here) indicates a proximity to land. The paleogeography of the area was described by Cariou et al. (1985) using invertebrate fossils and this agrees well with the interpretation of the two sequences studied.

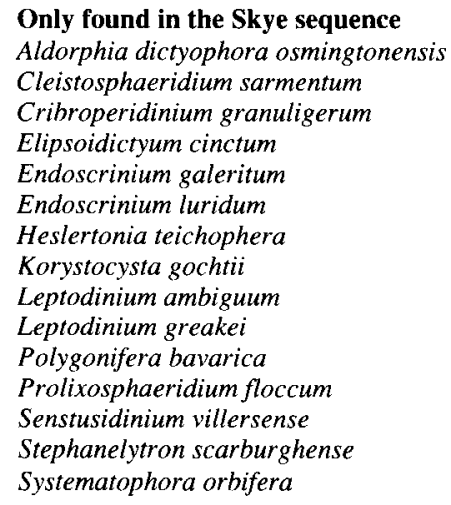

Only found in the South Dorset sequence

Atopodinium prostatum

Cleistosphaeridium? tribuliferum

Ctenidodinium tennellum

Fromea tornatilis

Liesbergia scarburghensis

Nannoceratopsis pellucida

Netrelytron stegastum

Rigaudella aemula

Senoniasphaera jurassica

Sirimiodiniopsis orbis
Table 1: Listing of dinoflagellate cysts not found in both sequences.

\section{ACKNOWLEDGEMENTS}

The author would like to thank Dr. J. B. Riding of the British Geological Survey and Dr. J. K. Wright of the University of London for providing the samples and field notes on which this study is based. The manuscript was prepared with the kind assistance of Dr. K. Natsuoka, Nagasaki University and the Amoco Tulsa Research Centre. Also, the encouragement and numerous discussions of ideas with Dr. W.A.S. Sarjeant were invaluable. The research was completed while the author was at the University of Saskatchewan funded by a University Graduate Scholarship.

Manuscript received October 1989

Revised Manuscript accepted August 1991

\section{REFERENCES}

Most references can be found in Lentin and Williams 1989. Listed below are others along with the citations of authors who published more than one referenced paper in a year, of which not all are to be found in the present paper.

Below, R. 1982. Rigaudella ein neues Genus von Dinoflagellaten Zysten. Neues Jb. Geol. Palaont., Mh., Stuttgart, 3, 137-150.

Cariou, E., Contini, D., Dommergues, J.L., Enay, R. Geyssant, J., Mangold, C. \& Thierry, J., 1985. Biogeographie des ammonites et evolution structurale de la Tethys au cours du Jurassique. Bull. Soc. geol. Fr., Paris, 8(1), 679697.

Cookson, I. C. and Eisenack, A. 1960. Upper Mesozoic microplankton from Australia and New Guinea. Palaeontoloqy, London, 2(2), 243-261.

Courtinat, B. 1989. Les organoclastes des formations lithologiques du Malm dans le Jura Meridional. Systematique, biostratigraphie et elements d'interpretation paleoecologique. Docums. Lab. Geol., Lyon, 105, 1-361.

Davey, R. 1969. Non-calcareous microplankton from the Cenomanian of England, northern France and North America, Part I. Bull. Br. Mus. Nat. Hist. Geology, London, 17, 103-180.

Davey, R. 1979, A re-appraisal of the genus Chytroeisphaeridia Sarjeant, 1962. Palynology, Dallas, 3, 209-218.

Davey, R. I., Downie, C., Sarjeant, W.A.S., \& Williams, G. L. 1966. Studies on Mesozoic and Cainozoic dinoflagellate cysts. Bull.Br. Mus. Nat. Hist. Geology, London, Supplement 3, 248 pp.

Deflandre, G., 1936. Microfossiles des silex cretaces. Premiere partie. Generalites. Flagelles. Annls Paleont., Paris, 25, 151-191.

Deflandre, G., 1937. Microfossiies des silex cretaces. Deuxieme partie. Flagelles Incertae sedis Hystrichosphaerides. Sarcodines. Organisms divers. Annls Paleont., Paris, 26, 51-103.

Deflandre, G., 1938. Microplancton des mers jurassiques conserve dans les marnes de Villers-sur-Mer (Calvados). Etude liminaire et considerations generales. Trav. Stn zool. Wimereux, Paris, 13, 147-200.

Deflandre, G., 1947, Sur quelques microorganismes planctoniques des silex Jurassiques. Bull. Inst. oceanogr. Monaco, 921, 1-10.

Downie, C.\& Sarjeant, W.A.S. 1964. Bibliography and index of dinoflagellates and acritarchs. Mem. geol. Soc. Am., Washington, 94, 1-180.

Gocht, H., 1970. Dinoflagellaten-Zystem aus dem Bathonium des Erdolfeldes Aldorf (NW-Deutschland) Palaeontographica, Abt. B, Stuttgart, 129, 125 165.

Ioannides, N. S., Stavrinos, G. N. and Downie, C. 1976. Kimmeridgian microplankton from Clavel's Hard, Dorset England. Micropaleontology, New York, 22, 443-478.

Jan du Chene, R. J. \& Masure, E. et al. 1986. Guide practique pour la determination de kyste de Dinoflagelles fossiles: le complexe Gonyaulacysta. Bull. Centres Rech. ExPlor. Prod.Elf Aquitaine, Memoire, Pau, 12, 1-479.

Lentin, J. K. and Williams, G. L. 1976. A monograph of fossil peridiniod dinoflagellate cysts. Bedford Institute of Oceanography Report Series, Dartmouth, BI-R-75-16, 1-237.

Lentin, J. K. \& Williams, G. L. 1989. Fossil dinoflagellates: index to genera and species Am. Assoc. Stratig. Palynol. Contrib. Ser., Dallas, 20, 1-473. 
Mehrotra, N. C. \& Sarjeant, W.A.S. 1984. The dinoflagellate cyst genus Polygonifera; emendation and taxonomic stabilization.J. Micropalaeont., London, 3(1), 43-53.

Sarjeant, W.A.S. 1960. New hystrichospheres from the Upper

Jurassic of Dorset. Geol. Mag., London, 97, 137-144.

Sarjeant, W.A.S., 1962. Microptankton from the Ampthill Clay of Mellon, South Yorkshire. Palaeontology, London, 5, 478-497.

Sarjeant, W.A.S., 1963. Two new Jurassic species of Gonyaulax (Dinophyceae). Rev. Micropaleont., Paris, 6, 85-88.

Sarjeant, W.A.S. 1966. Dinoflagellate cysts with Gonyaulax-type tabulation. In: Davey, R. J., Downie, C., Sarjeant, W.A.S. \& Williams, G. (eds), Studies on Mesozoic and Cainozoic dinoflaqellate cysts. Bull. Br. Mus. Nat. Hist. Geology, London, Supplement 3, 107-156.

Sarjeant, W.A.S., 1976a. Dinoflagellate cysts and acritarchs from the Great Oolite Limestone (Jurassic: Bathonian) of Lincolnshire, England. Geobios, 9, 5-46.

Sarjeant, W.A.S., 1976b. English Jurassic dinoflagellate cysts and acritarchs: a re-examination of some type and figured specimens. Geoscience and Man, Baton Rouge, 15, 1-24.

Sarjeant, W.A.S., 1978. A guide to the identification of Jurassic dinoflagellate cysts. Miscellaneous Publications, School of Geoscience, Louisiana State Universitv, Baton Rouge, 78(1), 1-107.

Sarjeant, W.A.S., 1980. Restudy of a 19th Century dinoflagellate cyst holotype from the Polish Upper Jurassic. Acta Palaeont. pol., Warsaw, 25, 279-285.

Sarjeant, W.A.S., 1982. The dinoflagellate cysts of the Gonyaulacysta group: a morphological and taxonomic study. Am. Assoc. Stratiqr. Palynol. Contrib. Ser., Dallas, 9, 1-80.

Sarjeant, W.A.S., 1984. A restudy of some dinoflagellate cysts and an acritarch from the Malm (Upper Jurassic) of Southwest Germany. Palaeontographica, Abt. B, Stuttgart, 191, 154-177.

Stancliffe R.P.W. \& Sarjeant, W.A.S. (1990). The complex chorate dinoflagellate cysts of the Bathonian to Oxfordian (Jurassic): their taxonomy and stratigraphic significance. Micropaleontology, New York, 36(3), 197 228.

Wetzel, O. 1933. Die in organischer Substanz erhaltenen Mikrofossilien des baltischen Kreide-Feuersteins mit einem sediment-petrographischen und stratigraphischen Anhang. Palaeontographica, Abt. A, 78(1-3), 1-110.

Williams, G. L. \& Bujak, J. P. 1985. Mesozoic - Cenozoic dinoflagellate zonations. In Bolli, H. M., Saunders, J. B. \& Perch-Nielsen, K. (Eds.), Plankton stratigraphy, Cambridge University Press, Cambridge, 847-964.

Williams, D. B. \& Sarjeant, W.A.S. 1967. Organic walled microfossils as depth and shoreline indicators. Marine Geol., Amsterdam, 5, 389-412.

Wright, J. K. 1973. The Middle and Upper Oxfordian and Kimmeridgian Staffin Shales at Staffin, Isle of Skye. Proc. Geol. Ass., London, 84, 447457.

Wright, J. K. , 1986. The Upper Oxford Clay at Furzy Cliff, Dorset: stratigraphy, palaeoenvironment and ammonite fauna. Proc. Geol. Ass., London, 97, 221-228. 